\title{
NMDA Receptors Containing the GluN2D Subunit Control Neuronal Function in the Subthalamic Nucleus
}

\author{
(i) Sharon A. Swanger, ${ }^{1 \star}$ Katie M. Vance, ${ }^{1 \star}$ Jean-François Pare, ${ }^{3}$ Florence Sotty, ${ }^{4}$ Karina Fog,${ }^{4}$ Yoland Smith, ${ }^{2,3}$ \\ and ${ }^{-S t e p h e n ~ F . ~ T r a y n e l i s ~}{ }^{1}$ \\ ${ }^{1}$ Department of Pharmacology and ${ }^{2}$ Department of Neurology, Emory University School of Medicine, Atlanta, Georgia 30322, ${ }^{3}$ Yerkes National Primate \\ Research Center and Morris K. Udall Center of Excellence for Parkinson's Disease Research, Emory University, Atlanta, Georgia 30329, and ${ }^{4} \mathrm{H}$. Lundbeck \\ A/S, Division of Neurodegeneration and Biologics, Ottiliavej 9, DK-2500 Valby, Denmark
}

The GluN2D subunit of the NMDA receptor is prominently expressed in the basal ganglia and associated brainstem nuclei, including the subthalamic nucleus (STN), globus pallidus, striatum, and substantia nigra. However, little is known about how GluN2D-containing NMDA receptors contribute to synaptic activity in these regions. Using Western blotting of STN tissue punches, we demonstrated that GluN2D is expressed in the rat STN throughout development [age postnatal day 7 (P7)-P60] and in the adult (age P120). Immunoelectron microscopy of the adult rat brain showed that GluN2D is predominantly expressed in dendrites, unmyelinated axons, and axon terminals within the STN. Using subunit-selective allosteric modulators of NMDA receptors (TCN-201, ifenprodil, CIQ, and DQP-1105), we provide evidence that receptors containing the GluN2B and GluN2D subunits mediate responses to exogenously applied NMDA and glycine, as well as synaptic NMDA receptor activation in the STN of rat brain slices. EPSCs in the STN were mediated primarily by AMPA and NMDA receptors and GluN2D-containing NMDA receptors controlled the slow deactivation time course of EPSCs in the STN. In vivo recordings from the STN of anesthetized adult rats demonstrated that the spike firing rate was increased by the GluN2C/D potentiator CIQ and decreased by the GluN2C/D antagonist DQP-1105, suggesting that NMDA receptor activity can influence STN output. These data indicate that the GluN2B and GluN2D NMDA receptor subunits contribute to synaptic activity in the STN and may represent potential therapeutic targets for modulating subthalamic neuron activity in neurological disorders such as Parkinson's disease.

Key words: excitatory synapse; GluN2B; GluN2D; glutamate receptor; NMDA; subthalamic nucleus

\section{Significance Statement}

The subthalamic nucleus (STN) is a key component of the basal ganglia, a group of subcortical nuclei that control movement and are dysregulated in movement disorders such as Parkinson's disease. Subthalamic neurons receive direct excitatory input, but the pharmacology of excitatory synaptic transmission in the STN has been understudied. Here, we show that GluN2B- and GluN2Dcontaining NMDA receptors mediate the NMDA receptor component of EPSCs in subthalamic neurons. Moreover, our results demonstrate that pharmacologic modulation of GluN2D-containing receptors alters the time course of EPSCs and controls the in vivo spike-firing rate in the STN. This study identifies GluN2D as a potential target for modulating subthalamic neuron activity.

\section{Introduction}

The subthalamic nucleus (STN) is the lone glutamatergic member of the basal ganglia, a group of interconnected subcortical

Received April 30, 2015; revised 0ct. 20, 2015; accepted 0ct. 29, 2015.

Author contributions: S.A.S., K.M.V., J.-F.P., F.S., K.F., Y.S., and S.F.T. designed research; S.A.S., K.M.V., J.-F.P., and F.S. performed research; S.A.S., K.M.V., J.-F.P., F.S., K.F., Y.S., and S.F.T. analyzed data; S.A.S., K.M.V., F.S., K.F., Y.S., and S.F.T. wrote the paper.

We thank Susan Jenkins for her help with immunocytochemistry and tissue processing, and Stefanie Ritter for her help with the GluN2D antibody. We also thank Jing Zhang, Anel Tankovic, and Phuong Le for excellent technical assistance. This work was supported by the NIH-NINDS [NS036654 and NS065371 (SFT), F32-NS086368 (SAS), T32-NS007480 (KMV)], NIH-NIDA T32-DA015040 (SAS and KMV), The Michael J. Fox Foundation (SFT), and a research grant to Emory University from Lundbeck A/S (SFT).

S.F.T. is a paid consultant for Neur0p and Janssen Pharmaceuticals and holds an equity position at NeurOp. The remaining authors declare no competing financial interests. nuclei that are critical for movement control. Neuronal activity in the STN provides the primary excitatory drive for the basal ganglia output nuclei, the globus pallidus internal, and substantia nigra pars reticulata (SNr; Bolam et al., 2000; Bevan et al., 2002; Wilson and Bevan, 2011). STN neurons exhibit autonomous firing that is driven by voltage-dependent sodium channels (Beurrier et al., 2000; Do and Bean, 2003; Surmeier et al., 2005; Atherton et al., 2008). Spike firing of subthalamic neurons is also

Correspondence should be addressed to Dr. Stephen F. Traynelis, Department of Pharmacology, Rollins Research Center, Emory University School of Medicine, 1510 Clifton Rd., Atlanta, GA 30322. E-mail: strayne@emory.edu. DOl:10.1523/JNEUROSCI.1702-15.2015

Copyright $\odot 2015$ the authors $\quad 0270-6474 / 15 / 3515971-13 \$ 15.00 / 0$ 
regulated by several types of afferents, including excitatory inputs from the cortex, thalamus, pedunculopontine nucleus, and superior colliculus (Afsharpour, 1985; Canteras et al., 1988; Féger et al., 1994; Nambu et al., 1996; Féger, 1997). STN neurons also recieve inhibitory inputs from the globus pallidus external (Smith and Grace, 1992; Shink et al., 1996; Bolam et al., 2002; Karachi et al., 2005) and dopaminergic inputs from the substantia nigra pars compacta (SNc) (Hassani et al., 1997; Prensa et al., 2000; Cragg et al., 2004). The loss of SNc neurons in Parkinson's disease leads to altered firing patterns in the STN, which correlates with the development of motor symptoms in patients and in animal models of the disease (Hamani et al., 2004; Wilson and Bevan, 2011). In addition, synchronous firing between the STN and motor cortex increases in the disease state, suggesting that activity at glutamatergic cortical inputs to the STN may be altered (Magill et al., 2001; Magill et al., 2004; Sharott et al., 2005; Kühn et al., 2006; Mallet et al., 2008; Litvak et al., 2011; Moran et al., 2011; Alegre and Valencia, 2013). Furthermore, exogenous activation of the corticosubthalamic projection can induce parkinsonian motor symptoms in rodents (Pan et al., 2014), indicating that glutamatergic neurotransmission in the STN has an integral role in basal ganglia function and movement.

Subthalamic neurons express mRNA encoding subunits in each ionotropic glutamate receptor class, including AMPA, kainate, and NMDA receptors (Sato et al., 1993; Bischoff et al., 1997; Wüllner et al., 1997; Clarke and Bolam, 1998; Jakowec et al., 1998). AMPA/kainate-type receptors mediate the fast component of EPSCs, whereas NMDA receptors mediate the slow component, which carries the majority of charge transfer and calcium influx during excitatory neurotransmission (Traynelis et al., 2010). NMDA receptors are typically composed of two glycinebinding GluN1 subunits and two glutamate-binding GluN2 subunits (Dingledine et al., 1999; Karakas and Furukawa, 2014; Lee et al., 2014). The GluN2 subunits, GluN2A-2D, confer distinct properties to the receptor, including pharmacology, deactivation time course, channel open probability, and sensitivity to magnesium inhibition (Traynelis et al., 2010). For example, GluN2Dcontaining NMDA receptors have a strikingly slow deactivation time course, low single channel open probability, and weak magnesium sensitivity compared with the other GluN2 subunits. In addition, GluN2 subunits have different regional expression patterns in the brain and in situ hybridization studies suggest that subthalamic neurons express mRNA encoding GluN2B and GluN2D (Monyer et al., 1994; Standaert et al., 1994; Wenzel et al., 1996). Agonist-evoked AMPA and NMDA receptor currents have been demonstrated in STN neurons (Götz et al., 1997; Awad et al., 2000; Lobo et al., 2003), but the roles for specific ionotropic glutamate receptors in synaptic transmission and spike firing in the STN have not been studied in detail.

The goal of this study was to determine which glutamate receptor subtypes mediate excitatory synaptic transmission in the STN, with a particular focus on determining the contribution of GluN2D-containing NMDA receptors. In addition, we tested whether modulating GluN2D-containing receptors influenced STN spike firing in vivo. Our results indicate that GluN2B- and GluN2D-containing receptors mediate the NMDA receptor component of EPSCs in the STN and that ongoing activation of GluN2D-containing NMDA receptors affects STN spike firing in vivo. These findings have important implications for the potential therapeutic regulation of STN spike activity.

\section{Materials and Methods}

Tissue punches and Western blotting. All procedures using animals were approved by the Institutional Animal Care and Use Committee of Emory University. Female Sprague Dawley rats [age postnatal day 7 (P7), P14, $\mathrm{P} 30, \mathrm{P} 60$, and P110-P120] and WT and GluN2D ${ }^{-1-}$ C57BL/6 mice of both sexes (age P28-P30) were killed by isoflurane overdose (Ikeda et al., 1995). The brains were removed and $200-300 \mu \mathrm{m}$ sagittal slices containing the STN were prepared in ice-cold PBS using a vibrating microtome. Tissue punches of the STN were removed using a 0.5 or $0.75 \mathrm{~mm}$ tissue punch (Stoelting) and then frozen on dry ice. The tissue was sonicated in lysis buffer, $\mathrm{pH} 7.4$, containing the following (in mM): $150 \mathrm{NaCl}, 50$ Tris, 50 NaF, 5 EDTA, 5 EGTA, 1\% Triton, 1\% SDS, and protease inhibitors. Protein concentrations were determined by the Bradford assay and then the samples were diluted with lysis buffer and $2 \times$ Laemmli buffer to a final concentration of $0.5 \mu \mathrm{g} / \mu \mathrm{l}$. After heating at $95^{\circ} \mathrm{C}$ for $5 \mathrm{~min}, 5-10 \mu \mathrm{g}$ of total protein was loaded on a $4-15 \%$ SDS-PAGE gel. Proteins were transferred to PVDF membranes for Western blotting. The antibodies used were mouse anti-GluN2D (Millipore, MAB5578, 1:5000), mouse anti-tubulin (Sigma-Aldrich, 1:50,000), and HRP-conjugated goat antimouse (Jackson Immunoresearch, 1:10,000). Membranes were stripped with Restore Stripping Buffer (Pierce) for $15 \mathrm{~min}$ and washed before being reprobed with additional primary antibodies. Chemiluminescence signals were detected with film, which were imaged with the Bio-Rad Gel Doc Imager and analyzed by densitometry using ImageJ.

Immunohistochemistry and electron microscopy. Adult Sprague Dawley rats and adult WT and GluN2D ${ }^{-1-}$ C57BL/6 mice of both sexes were used for histology experiments. The animals were anesthetized with pentobarbital and perfusion fixed with a mixture of $4 \%$ paraformaldehyde and $0.1 \%$ glutaraldehyde (Galvan et al., 2006; Kuwajima et al., 2007). The brains were then cut into $60-\mu \mathrm{m}$-thick sections with a vibratome and processed for the light and electron microscopic localization of the GluN2D subunit using well characterized commercially available antibodies: mouse anti-GluN2D (Millipore, MAB5578) or goat antiGluN2C/D (Santa Cruz Biotechnology, sc-31551; Laurie et al., 1997). The avidin-biotin peroxidase method and 3,3' diaminobenzidine were used to visualize the reaction product of GluN2D immunoreactivity. Sections of the STN were prepared for electron microscopy as previously described (Kuwajima et al., 2004; Galvan et al., 2006; Kuwajima et al., 2007). One block of tissue was taken out from the STN in each animal, cut in ultrathin sections with an Ultramicrotome (Ultracut T2; Leica), mounted on copper grids, and examined in the electron microscope (model 1011; Jeol, Peabody, MA). At the electron microscopic level, the STN tissue was scanned, and a series of 50 micrographs of randomly distributed immunoreactive profiles were taken at $40,000 \times$. The different labeled elements were categorized as dendrites, terminals, axons, or glia according to their ultrastructural features (Peters et al., 1991).

Cell culture and molecular biology. Cells from the human embryonic kidney-293 cell line (CRL 1573; ATCC; hereafter HEK cells) were plated on glass coverslips (Warner Instruments) coated with $100 \mu \mathrm{g} / \mathrm{ml}$ poly-Dlysine. Cells were maintained in $5 \%$ humidified $\mathrm{CO}_{2}$ at $37^{\circ} \mathrm{C}$ in Dulbecco's Modified Eagle Medium with Glutamax (Invitrogen) supplemented with $10 \%$ fetal bovine serum, 10 units $/ \mathrm{ml}$ penicillin, and $10 \mu \mathrm{g} / \mathrm{ml}$ streptomycin. The Fugene6 transfection reagent (Roche Diagnostics) was used to transiently transfect HEK cells with cDNA encoding GFP, GluN1, and GluN2 at a ratio of 1:1:1. The cDNAs used were rat NMDA receptor subunits GluN2B (GenBank U11419), GluN2D (GenBank L31611), GluN1-1a (GenBank U11418, U08261), and GluN1-1b (GenBank U08263). The transfected cells were incubated in media supplemented with NMDA receptor antagonists D,L-2-amino-5-phosphonovalerate (200 $\mu \mathrm{M}$; D,L-APV) and 7-chlorokynurenic acid (200 $\mu \mathrm{M}$; 7-CKA).

Patch-clamp recordings from transfected HEK cells. Voltage-clamp recordings were made from transfected cells lifted from the coverslip $\left(V_{\text {HOLD }}\right.$ $-60 \mathrm{mV}$, Axopatch 200B amplifier; Molecular Devices). Recordings were digitized at $40 \mathrm{kHz}$ using Axon pClamp10 software and filtered at 8 $\mathrm{kHz}$ using an eight-pole Bessel filter ( $-3 \mathrm{~dB}$; Frequency Devices). Electrodes were made from thin-walled borosilicate glass (Warner Instruments) and were filled with an internal solution containing the following 
(in mM): 110 Cs-gluconate, $30 \mathrm{CsCl}, 5$ HEPES, $4 \mathrm{NaCl}, 0.5 \mathrm{CaCl}_{2}, 2$ $\mathrm{MgCl}_{2}, 5$ BAPTA, $2 \mathrm{Na}_{2} \mathrm{ATP}$, and 0.3 NaGTP, pH 7.35, $295 \mathrm{M} \Omega$. Cells were bathed in an external solution containing the following (in $\mathrm{mM}$ ): $150 \mathrm{NaCl}, 10 \mathrm{HEPES}, 30 \mathrm{D}-$ mannitol, $3 \mathrm{KCl}, 0.5 \mathrm{CaCl}_{2}$, and 0.01 EDTA, $\mathrm{pH}$ 8.0. A Warner Instruments TC-344B temperature controller maintained the temperature of the external solution $\left(23^{\circ} \mathrm{C}\right.$ or $\left.32^{\circ} \mathrm{C}\right)$. Rapid solution exchange for whole-cell voltage-clamp recordings of HEK cells was performed using a two-barrel theta glass pipette controlled by a piezoelectric translator (Burleigh Instruments). The open tip 10-90\% rise time of the solution exchange was $<0.6 \mathrm{~ms}$ and the solution exchange time (10-90\%) around a whole cell was $\sim 3 \mathrm{~ms}$ (Vance et al., 2012).

Patch-clamp recording from neurons in the STN. Sprague Dawley rats (aged P11-P18) as well as WT or GluN2D ${ }^{-1-}$ C57BL/6 mice (aged P14$\mathrm{P} 20)$ of both sexes were killed by isoflurane overdose and decapitated. The brain was rapidly removed, hemisected, and glued to the stage of a vibrating microtome (Leica VT1000S or VT1200S). Sagittal brain slices $(250 \mu \mathrm{m})$ were cut in ice-cold artificial CSF (aCSF) composed of (in mM): $130 \mathrm{NaCl}, 24 \mathrm{NaHCO}_{3}, 10$ glucose, $3 \mathrm{KCl}, 3 \mathrm{MgSO}_{4}, 1.25 \mathrm{NaH}_{2} \mathrm{PO}_{4}$, and $1 \mathrm{CaCl}_{2}$ that was saturated with $95 \% \mathrm{O}_{2} / 5 \% \mathrm{CO}_{2}$. For some experiments, after isoflurane overdose, the animals were transcardially perfused with an ice-cold sucrose-based aCSF solution containing the following (in $\mathrm{mm}$ ): 230 sucrose, $24 \mathrm{NaHCO}_{3}, 10$ glucose, $3 \mathrm{KCl}, 10 \mathrm{MgSO}_{4}, 1.25$ $\mathrm{NaH}_{2} \mathrm{PO}_{4}$, and $0.5 \mathrm{CaCl}_{2}$ and saturated with $95 \% \mathrm{O}_{2} / 5 \% \mathrm{CO}_{2}$ before the slicing procedure described above. All slices were incubated at room temperature in the $\mathrm{NaCl}$-based aCSF solution for at least $1 \mathrm{~h}$ before use and recordings were performed at $32^{\circ} \mathrm{C}$. The external aCSF solution for the slice recordings contained the following (in $\mathrm{mm}$ ): $130 \mathrm{NaCl}, 24$ $\mathrm{NaHCO}_{3}, 10$ glucose, $3 \mathrm{KCl}, 0.2-1.5 \mathrm{MgSO}_{4}, 1.5-4 \mathrm{CaCl}_{2}$, and 1.25 $\mathrm{NaH}_{2} \mathrm{PO}_{4}$ saturated with $95 \% \mathrm{O}_{2} / 5 \% \mathrm{CO}_{2}$. Recording electrodes were filled with a solution containing the following (in mM): 120 Csmethanesulfonate, $15 \mathrm{CsCl}, 10$ tetraethylammonium chloride, 10 HEPES, $8 \mathrm{NaCl}, 3 \mathrm{Mg}$-ATP, $1.5 \mathrm{MgCl}_{2}$, 1 QX-314, $0.3 \mathrm{Na}-\mathrm{GTP}$, and 0.2 EGTA, pH 7.3 (Guzman et al., 2009). Recordings were made using either an Axopatch 200A or Axopatch 200B amplifier (Molecular Devices), digitized at $20 \mathrm{kHz}$ using Axon pClamp8 software, and filtered at $2 \mathrm{kHz}$ using an eight-pole Bessel filter ( $-3 \mathrm{~dB}$; Frequency Devices).

A Picospritzer II (Parker Hannifin) was used to evoke currents by pressure applying brief pulses (4-12 psi; 3-100 ms) of NMDA (1 mM) and glycine $(0.003-0.5 \mathrm{~mm})$ through a borosilicate capillary tube $(3.5$ $\mathrm{M} \Omega$ ). During the picospritzer recordings, the external solution was supplemented with $0.5 \mu \mathrm{M}$ TTX, $10 \mu \mathrm{M}$ bicuculline, and $5 \mu \mathrm{M}$ nimodipine (Lee et al., 2007). Voltage-clamp recordings were obtained at a $V_{\text {HOLD }}$ of $-60 \mathrm{mV}$ and the recording solutions contained $0.2 \mathrm{mM} \mathrm{Mg}^{2+}$. Three to 10 stable control measurements were obtained in the presence of aCSF at $30-90$ s intervals. The NMDA receptor modulator (prepared in the aCSF external solution) or vehicle was bath applied for 5-15 min while currents were continuously evoked by pressure application of NMDA and glycine. After bath application of the modulator, the slice was washed with the control aCSF solution and NMDA/glycine continued to be pressure applied at the same interval. Finally, the NMDA receptor competitive antagonist D,L-APV $(400 \mu \mathrm{M})$ was bath applied during NMDA and glycine applications to inhibit the NMDA receptor response (Lee et al., 2007).

EPSCs were evoked by injecting $50-500 \mu \mathrm{A}$ of current for $0.1 \mathrm{~ms}$ using a bipolar tungsten-stimulating electrode (FHC) placed near the internal capsule fibers rostral to the STN (Baufreton et al., 2009; Yamawaki et al., 2012). EPSCs were evoked every $30 \mathrm{~s}$ and the recordings were conducted using the external solution described above supplemented with $10 \mu \mathrm{M}$ bicuculline and $10 \mu \mathrm{M}$ DNQX. Voltage-clamp recordings were performed at $-40 \mathrm{mV}$ or $+40 \mathrm{mV}$ with $0.2 \mathrm{~mm}$ or $1.5 \mathrm{mM} \mathrm{Mg}^{2+}$, respectively, in the recording solutions. Paired-pulse recordings were performed at $-40 \mathrm{mV}$ in $10 \mu \mathrm{M}$ bicuculline, $1 \mathrm{mM} \mathrm{Mg}^{2+}$, and $4 \mathrm{~mm}$ $\mathrm{Ca}^{2+}$. For the paired-pulse recordings, EPSCs were evoked every $30 \mathrm{~s}$ by a pair of stimuli separated by $50 \mathrm{~ms}$. The $I_{\mathrm{h}}$ current was recorded under current-clamp conditions using the same intracellular solution by injecting $0.1 \mathrm{nA}$ of hyperpolarizing current into the cell for $1 \mathrm{~s}$.

Analysis of voltage-clamp recordings. The individual sweeps of wholecell voltage-clamp recordings from HEK cells and subthalamic neurons were averaged and preapplication baseline subtracted. ChanneLab or
Clampfit was used to determine current amplitude, the $10-90 \%$ rise time of peak amplitude, charge transfer, and the deactivation time constants. The deactivation time constants of whole-cell voltage-clamp recordings from HEK cells and evoked EPSCs from subthalamic neurons were calculated by fitting the following equation to the data:

Response $=\operatorname{Amp}_{\mathrm{FAST}} \exp \left(-\right.$ time $\left./ \tau_{\mathrm{FAST}}\right)$

$$
+\operatorname{Amp}_{\text {sLow }} \exp \left(- \text { time } / \tau_{\text {sLOW }}\right)
$$

Where $\tau_{\text {FAST }}$ is the fast deactivation time constant, $\tau_{\text {SLOW }}$ is the slow deactivation time constant, Amp FAST $_{\text {is }}$ is the current amplitude of the fast deactivation component, and Amp sLow is the current amplitude of the slow deactivation component. Weighted deactivation time constants $\left(\tau_{\mathrm{W}}\right)$ were calculated using the following equation:

$$
\begin{aligned}
& \tau_{\mathrm{W}}=\left[\mathrm{Amp}_{\mathrm{FAST}} /\left(\mathrm{Amp}_{\mathrm{FAST}}\right.\right.\left.+\mathrm{Amp}_{\mathrm{SLOW}}\right] \tau_{\mathrm{FAST}} \\
&+\left[\mathrm{Amp}_{\mathrm{SLOW}} /\left(\mathrm{Amp}_{\mathrm{FAST}}+\mathrm{Amp}_{\mathrm{SLOW}}\right)\right] \tau_{\mathrm{SLOW}}
\end{aligned}
$$

In vivo extracellular recordings of STN neuronal activity. All in vivo rat spike-firing experiments were performed in accordance with the European Communities Council Directive (86/609/EEC) for the care and use of laboratory animals and the Danish legislation regulating animal experiments. The Danish Animal Experiments Inspectorate approved the protocols (journal no 2004/561-798). For all experiments, rats were housed two per cage under a $12 \mathrm{~h}$ light/dark cycle (lights on at 6:00 A.M.) in a temperature $\left(21 \pm 2^{\circ} \mathrm{C}\right)$ - and humidity $(60 \pm 10 \%)$ - controlled environment. Rats were allowed to acclimate for 5-7 d before experimentation with ad libitum access to rat chow and tap water.

For recordings of neurons in the STN, male Wistar rats (Charles River) weighing 280-360 g were used. Animals were anesthetized with an intraperitoneal injection of urethane $(1.2-1.5 \mathrm{~g} / \mathrm{kg})$. Animals were then mounted in a stereotaxic frame, the skull was exposed, and a hole $\sim 3 \times$ $3 \mathrm{~mm}$ was drilled above the STN (see coordinates below). Extracellular single-cell recordings were performed using an assembly consisting of a recording glass electrode and an ejection pipette allowing local drug delivery. The recording glass micropipette was first pulled and broken at an external diameter of $2-4 \mu \mathrm{m}$ and was subsequently bent by heating the shank $\sim 7 \mathrm{~mm}$ from the tip. The ejection pipette was prepared from glass tubing with an internal diameter of $0.3 \mathrm{~mm}$ and calibrated at 15 $\mathrm{mm} / \mu \mathrm{l}$ (Assistent, ref. 555/5) and was pulled and broken back to an external diameter of $50 \mu \mathrm{m}$. The ejection pipette then was positioned under microscopic control and, by means of micromanipulators, immediately adjacent to and $40-60 \mu \mathrm{m}$ above the tip of the bent recording electrode. Both pipettes were permanently jointed with an ultravioletsensitive resin. Ejection pipettes were filled through the tip by negative pressure with NMDA modulators at various concentrations dissolved in PBS solution $\left(\mathrm{NaCl} 8 \mathrm{~g} / \mathrm{L}, \mathrm{KCl} 0.2 \mathrm{~g} / \mathrm{L}, \mathrm{Na}_{2} \mathrm{HPO}_{4}-2 \mathrm{H}_{2} \mathrm{O} 1.44 \mathrm{~g} / \mathrm{L}\right.$, $\mathrm{KH}_{2} \mathrm{PO}_{4} 0.2 \mathrm{~g} / \mathrm{L}$, and $\mathrm{CaCI}_{2}-2 \mathrm{H}_{2} \mathrm{O} 132 \mathrm{mg} / \mathrm{L}$ ). The recording electrode was filled with $2 \%(\mathrm{w} / \mathrm{v})$ Pontamine Sky Blue in $0.5 \mathrm{~m}$ sodium acetate solution and had an impedance of 2-10 $\mathrm{M} \Omega$ at $135 \mathrm{~Hz}$.

The assembly was then lowered into the brain using a hydraulic microdriver at the following coordinates: AP $4.2-3.6 \mathrm{~mm}$ posterior to bregma; L 2.2-2.8 mm lateral to the midline. Extracellular action potentials were amplified, discriminated, and monitored on an oscilloscope and an audiomonitor. Discriminated spikes were collected and analyzed using Spike 2 software (Cambridge Electronic Design) on a PC-based system connected to a CED 1401 interface unit (Cambridge Electronic Design). Presumed glutamatergic neurons from the STN typically were found 7.4-8.0 $\mathrm{mm}$ beneath the surface of the brain according to the rat brain atlas (Paxinos and Watson, 1998) and all exhibited a biphasic, positive-negative waveform. Once a neuron was isolated and its baseline firing rate was stable for at least $5 \mathrm{~min}$, drug application close to the recorded neuron was initiated by applying repeated pressure pulses (10-40 ms duration; $10-20$ psi) with the assistance of a Picospritzer III (Intracell). A small volume (3-6 nl) typically was applied to minimize mechanical distortion and was followed under microscopic control by the movement of the solution meniscus in the pipette. Repeated ejections 
were performed to assess reproducibility of the drug effects at a minimum interval of $4 \mathrm{~min}$.

The NMDA receptor modulator CIQ was either applied alone (10-20 $\mu \mathrm{M})$ or in combination with MK-801 $(2.5 \mu \mathrm{M})$. The change in firing rate induced by drug application was compared with the baseline firing rate by measuring the maximal firing rate during either the last $10-20 \mathrm{~s}$ of drug application for CIQ or the 10-20 min period after DQP-1105 application, which was then expressed as percentage of baseline firing rate measured 3-5 min before drug application. For MK-801 coapplication experiments, because a decrease in the baseline firing rate typically was observed over time after MK-801 application, the baseline firing rate measured before each drug application was subtracted from the maximal firing rate during the last $10-20 \mathrm{~s}$ of drug application. The responses evoked by the second through fifth applications were then expressed as a percentage of the response evoked by the first drug application.

Statistical analysis. The data were analyzed and plotted in GraphPad Prism 5 or Origin Lab 9.0. The Shapiro-Wilk's test was used to test for normality and Levene's test was used to test for homogeneity of variances. The data were then analyzed using appropriate parametric or nonparametric tests with corrections for multiple comparisons as stated in the figure legends. Normal data are reported as mean \pm SEM and nonnormal data are reported as median and $25-75 \%$ interquartile range (IQR). Significance for all tests was set at $p<0.05$.

\section{Results}

\section{GluN2D subunit is expressed in subthalamic neurons}

GluN2D expression levels are developmentally regulated in some brain regions, many of which show a marked decrease in expression during postnatal development (Dunah et al., 1996; Wenzel et al., 1996; Laurie et al., 1997; Lau et al., 2003; Shibata et al., 2003; Liu and Wong-Riley, 2010). To evaluate GluN2D expression in the STN, tissue punches were harvested from the STN of rats aged P7, P14, P30, P60, and P110-P120 (Fig. 1A) and then analyzed by Western blotting using a monoclonal antibody against GluN2D. GluN2D expression was observed in the STN at all of the ages analyzed in this study and there was no significant change in GluN2D levels between age groups $(n=3-4$ animals per group; Fig. $1 B, C)$. Tissue punches from WT and GluN2D ${ }^{-1-}$ mice (Ikeda et al., 1995) were used to demonstrate the specificity of the GluN2D antibody ( $n=3$ animals; Fig. $1 C)$. Importantly, these data demonstrate that the GluN2D subunit is expressed in the rat STN throughout postnatal development and in adulthood. In addition, brain sections from WT and GluN2D ${ }^{-1-}$ mice were immunostained with a polyclonal antibody that detects the GluN2C and GluN2D subunits. Using light microscopy, strong immunoreactivity was apparent in WT STN, whereas the faint staining detected in GluN2D ${ }^{-/-}$sections was similar to background levels in control WT sections incubated without primary antibodies (Fig. 1D). These data suggest that GluN2D is expressed in the STN of adult mice and also support data from previous in situ hybridization studies showing no detectable GluN2C expression in the STN (Monyer et al., 1994; Standaert et al., 1994; Wenzel et al., 1997).

Next, the subcellular distribution of GluN2D protein was evaluated in the rat STN using immunostaining and electron microscopy. GluN2D localization was analyzed by immunostaining with either the GluN2C/D polyclonal antibody or the monoclonal antibody against GluN2D used in Figure 1. Analysis of electron micrographs suggested that the GluN2D subunit was expressed predominantly in dendrites of subthalamic neurons (Fig. $2 A, B, D$ ); $66 \pm 3.0 \%$ (monoclonal), and $64 \pm 3.2 \%$ (polyclonal) of the total labeled elements were accounted for by dendritic profiles. Albeit less frequent, GluN2D-positive labeling was also found presynaptically in unmyelinated axons (14.5 $\pm 1.3 \%$
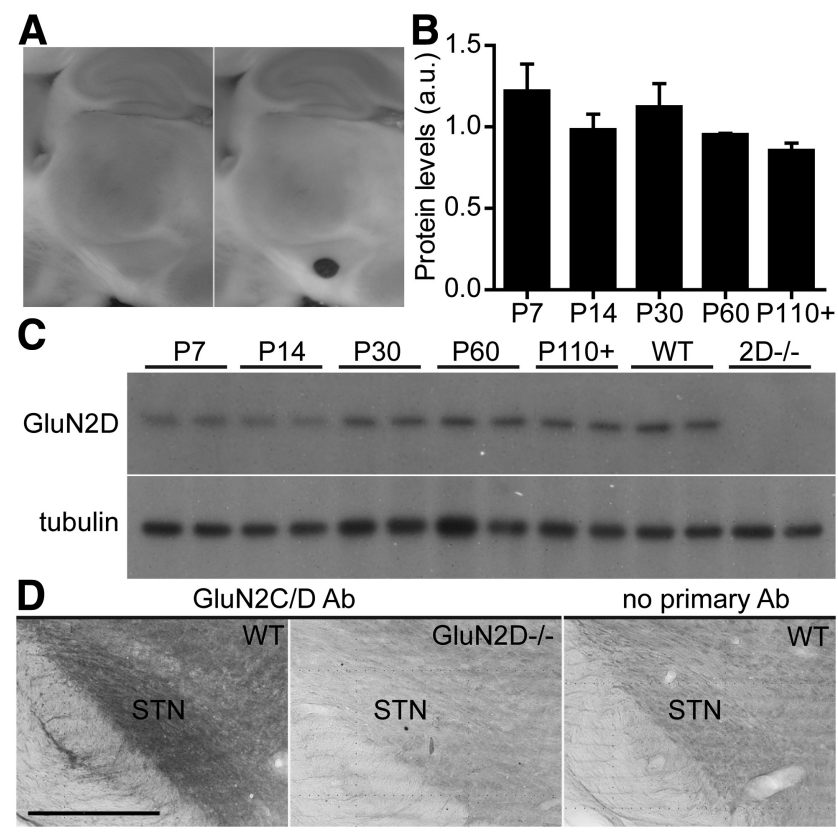

Figure 1. GluN2D protein expression during postnatal development. $\boldsymbol{A}$, Brain slices are shown before (left) and after (right) removal of the STN by a tissue punch. $B$, GluN2D expression in STN tissue punches obtained from rats aged P7, P14, P30, P60, and P110 - P120 (P110+) was evaluated by Western blot. Densitometry measurements for GluN2D levels were normalized to tubulin levels, plotted as mean \pm SEM, and analyzed by one-way ANOVA ( $n=3-4$ animals per group, $F_{(4,11)}=2.153, p=0.142$ ). Measurements from two replicate Western blots were averaged for each animal. $C$, Representative Western blots of GluN2D and tubulin show protein samples from two different animals for each age group. $D$, Immunoperoxidase labeling from polyclonal GluN2C/D antibodies is shown in the STN of WT mice (left) and GluN2D ${ }^{-1-}$ mice (center). The right panel shows peroxidase labeling in WT tissue incubated without primary antibodies. Scale bar, $0.5 \mathrm{~mm}$.

and $14.3 \pm 2.3 \%$ total labeled elements, respectively; Fig. $2 C, E$ ) and axon terminals $(17.3 \pm 2.8 \%$ and $23.3 \pm 1.4 \%$ total labeled elements, respectively), some of which displayed the ultrastructural features of putative pallidal GABAergic terminals (Fig. $2 A, F)$. Occasionally, the peroxidase deposit in the labeled dendrites was aggregated at the postsynaptic densities of asymmetric synapses (Fig. $2 B, D$ ). Overall, the patterns of STN labeling obtained with both the polyclonal GluN2C/D and the monoclonal GluN2D antibodies were similar despite the different epitopes of the two antibodies (Fig. 2G). Altogether, these data provide strong evidence that GluN2D is expressed in subthalamic neurons and could regulate synaptic transmission in the STN.

\section{Agonist-evoked NMDA receptor currents in the STN are mediated by GluN2B- and GluN2D-containing receptors} To determine which GluN2 subunits contributed to NMDA receptor currents in subthalamic neurons, we tested the effects of GluN2 subunit-selective modulators on agonist-evoked responses in brain slices from rats aged P11-P18. NMDA (1 mM) and glycine $(0.5 \mathrm{mM})$ were ejected from a micropipette by brief pressure pulses and NMDA receptor modulators were bath applied to the slices (Fig. 3A). The GluN2B-selective inhibitor ifenprodil ( $3 \mu \mathrm{M}$; Williams, 1993) reduced the peak amplitude of NMDA- and glycine-evoked currents to $62 \pm 8.1 \%$ of the baseline response in aCSF $(n=6$; Fig. $3 B, C)$. Next, we tested whether agonist-evoked currents could be modulated by the GluN2C/Dselective inhibitor DQP-1105 (Acker et al., 2011) and GluN2C/ D-selective positive allosteric modulator CIQ (Mullasseril et al., 2010). DQP-1105 (20 $\mu \mathrm{M})$ inhibited current amplitudes to 

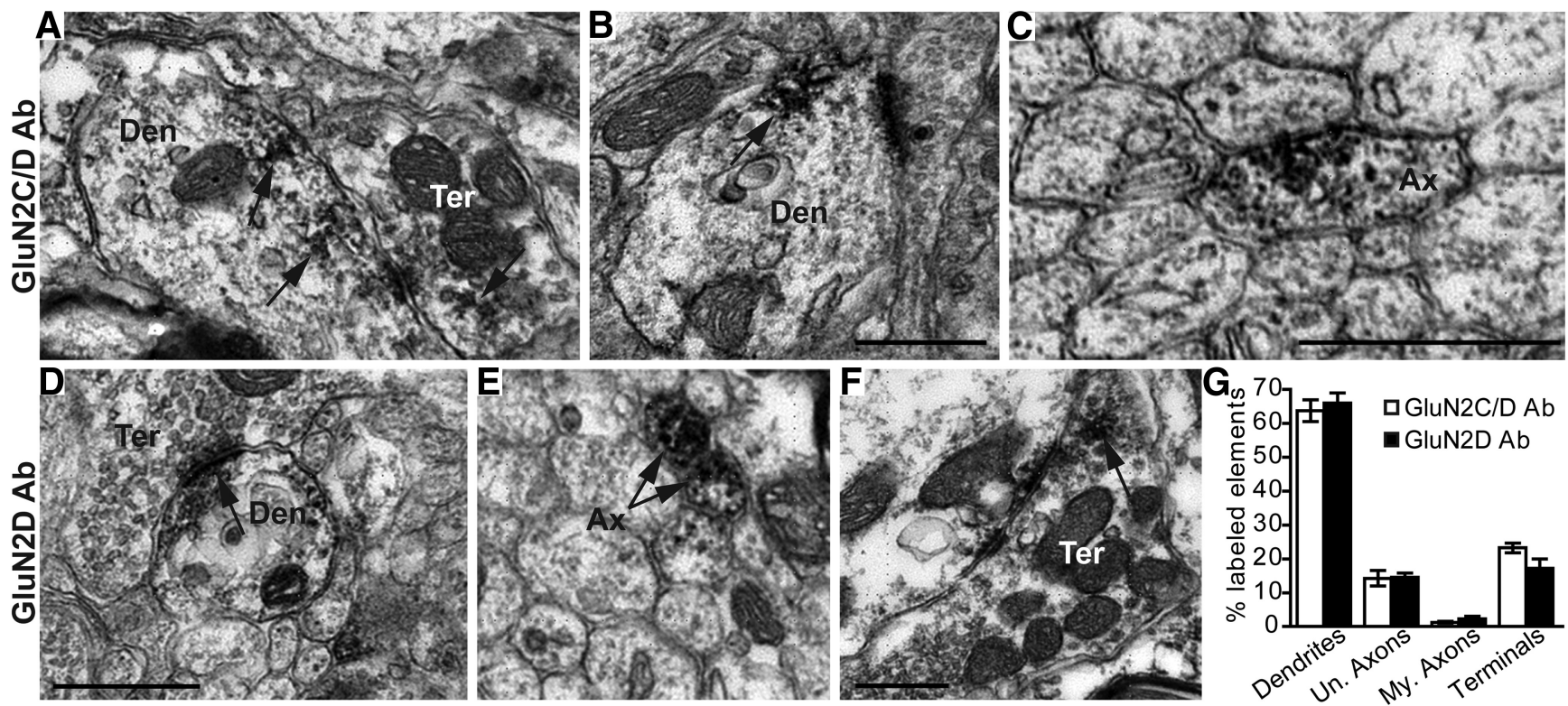

Figure 2. Analysis of ultrastructural features of GluN2D-immunoreactive elements in the STN. Electron micrographs of rat STN show GluN2C/D immunoreactivity in an axon terminal (Ter; $A$ ), dendrites (Den; $\boldsymbol{A}, \boldsymbol{B})$, and an unmyelinated axon $(\mathrm{Ax} ; \boldsymbol{C})$ in the STN neuropil. The arrows indicate aggregates of peroxidase labeling. Electron micrographs of the rat STN show immunoperoxidase labeling from a monoclonal GluN2D antibody close to the postsynaptic density of an asymmetric synapse (arrow) in the dendrite (Den; $\boldsymbol{D}$ ), in unmyelinated axons (Ax, arrows; $\boldsymbol{E}$ ), and in an axon terminal forming a symmetric synapse with a large dendrite in the STN (Ter, arrow; $\boldsymbol{F})$. $\mathbf{G}$, Histogram showing the relative percentages of different types of labeled elements in the STN immunostained with either the polyclonal GluN2C/D or monoclonal GluN2D antibodies ( $n=4$ animals). Error bars indicate SEM. Scale bars, $0.5 \mu \mathrm{m}$. The scale bar in $\boldsymbol{B}$ is valid for $\boldsymbol{A}$ and the scale bar in $\boldsymbol{D}$ is valid for $\boldsymbol{E}$.

$65.0 \pm 5.5 \%$ of baseline responses $(n=6$; Fig. $3 B, D)$, and CIQ $(20 \mu \mathrm{M})$ potentiated current amplitudes to $150 \pm 8.6 \%$ of baseline aCSF responses $(n=6$; Fig. $3 B, E)$. In addition, we evaluated whether the GluN2A-selective inhibitor TCN-201 affected agonist-evoked responses in the STN (Bettini et al., 2010; Edman et al., 2012; Hansen et al., 2012). We used $3 \mu \mathrm{M}$ glycine because TCN-201 has been shown to be less effective at higher concentrations of glycine (Hansen et al., 2012). TCN-201 did not affect the peak amplitude of the currents $(100 \pm 3.2 \%$ of baseline, $n=6$; Fig. $3 B$ ) compared with the vehicle control (102 $\pm 2.2 \%$ of baseline, $n=5)$. As a positive control, TCN-201 significantly reduced NMDA receptor currents recorded from cerebellar granule cells cultured in elevated potassium, which is known to promote expression of GluN2A ( $31 \pm 3.9 \%$ of control, $n=7$, paired $t$ test, $p=0.006$; Zheng et al., 2001). In each experiment, the agonistevoked responses were blocked by application of D,L-APV, indicating that the currents were mediated by NMDA receptors (e.g., Fig. $3 C-E$ ). We interpret these data to suggest that the GluN2B and GluN2D subunits are the primary GluN2 subunits expressed in the developing rat STN, which is consistent with previous reports showing GluN2B and GluN2D mRNA expression in the STN (Monyer et al., 1994; Standaert et al., 1994).

\section{STN EPSCs are mediated by AMPA and NMDA receptors}

To assess how ionotropic glutamate receptors contribute to synaptic currents in the STN, EPSCs were evoked using a stimulating electrode placed in the internal capsule and the NMDA, AMPA, and kainate receptor components of the EPSC were isolated pharmacologically (Fig. 4A; Baufreton et al., 2009). We first assessed the $\mathrm{Mg}^{2+}$ sensitivity of the NMDA receptor component (NMDAR-EPSCs) by evaluating the current-voltage relationship for EPSCs at $0.2 \mathrm{mM}$ and $1.5 \mathrm{mM} \mathrm{Mg}^{2+}$ in the presence of the AMPA/kainate receptor antagonist DNQX ( $n=4$; Fig. $4 B)$. NMDAR-EPSCs showed moderate voltage-sensitive $\mathrm{Mg}^{2+}$ block when recorded at $-40 \mathrm{mV}$ in aCSF containing $0.2 \mathrm{mM} \mathrm{Mg}^{2+}$ compared with that observed at $1.5 \mathrm{mM} \mathrm{Mg}^{2+}$. Therefore, we determined the total contribution of NMDA receptors to synaptic currents by applying DNQX $(20 \mu \mathrm{M})$ and evoking EPSCs at a holding potential of $+40 \mathrm{mV}$ with $1.5 \mathrm{~mm} \mathrm{Mg}^{2+}$. After DNQX application, the peak amplitude of the remaining EPSC was $53.7 \%$ (median) of the baseline EPSC amplitude in aCSF (IQR = 24.3-63.8, $n=14$; Fig. 4C,D). In addition, DNQX slowed the EPSC deactivation time course compared with the aCSF control (Table 1), which is consistent with NMDA receptors mediating the slow component of the EPSC time course in the STN.

AMPA and kainate receptor currents were isolated by inhibiting NMDA receptors with $400 \mu \mathrm{M}$ D,L-APV and $50 \mu \mathrm{M}$ 7-CKA, which reduced the peak current to $36.7 \%$ (median) of the baseline EPSC amplitude in aCSF (IQR $=27.0-47.0 \%, n=8$; Fig. $4 C, D)$. As expected, inhibition of NMDA receptors significantly accelerated the decay time for the EPSC (Table 1). To study the contribution of kainate receptors alone, we applied $400 \mu \mathrm{M} \mathrm{D}, \mathrm{L}-$ APV and $50 \mu \mathrm{M} 7-\mathrm{CKA}$ (to inhibit NMDA receptors) plus $100 \mu \mathrm{M}$ GYKI-52466, a selective noncompetitive antagonist for AMPA receptors (Mott et al., 2008). Under these conditions, we detected a residual postsynaptic current in four of eight neurons tested. The peak amplitude of the remaining currents had a median value of $10.7 \%$ of the baseline response in aCSF (IQR $=5.4-$ $19.2 \%, n=4$ ) and these remaining currents were subsequently blocked by AMPA/kainate receptor antagonist DNQX, suggesting that they may be mediated by kainate receptors. In the other four neurons, inhibition of only NMDA and AMPA receptors blocked the entire EPSC, suggesting that kainate receptors are not expressed at all synapses in the STN. The overall median of kainate receptor responses was $2.2 \%$ of the total EPSC amplitude, which was not significantly different from zero (IQR $=0-11.7 \%$, $n=8$, Wilcoxon's signed-rank test, $p=0.125$ ). The deactivation time course of kainate receptor currents was faster than that of the total EPSC, but not significantly different from the combined AMPA/kainate receptor response (Table 1). Therefore, it is pos- 
A
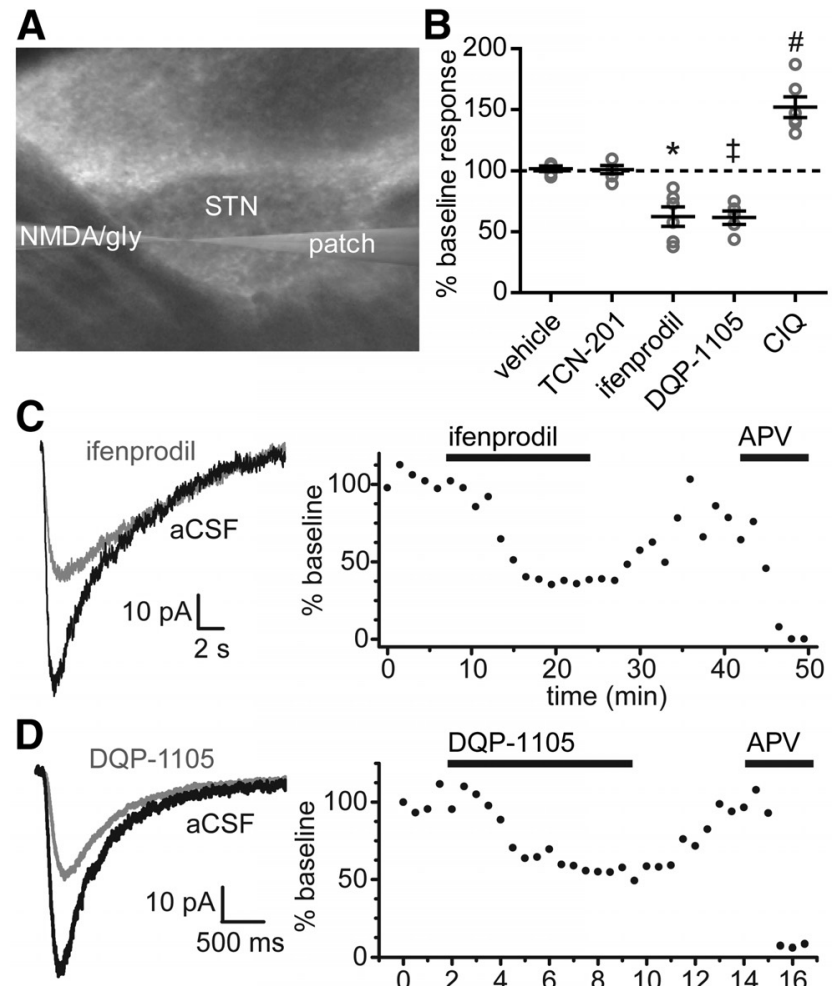

E

E aCSF
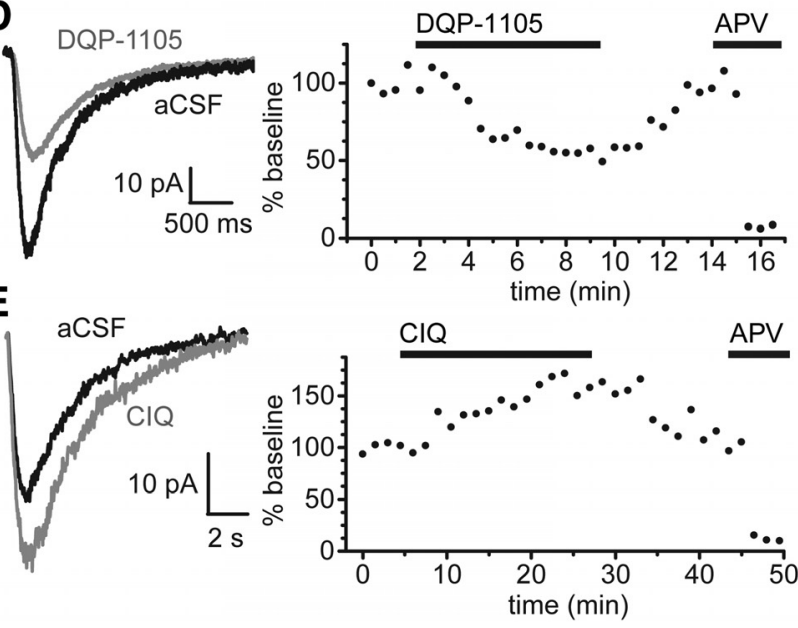

Figure 3. NMDA- and glycine-evoked currents are potentiated or inhibited by GluN2B and GluN2D subunit-specific modulators. $A$, Brief pulses (3-100 ms) of NMDA (1 mM) and glycine $(0.003-0.5 \mathrm{~mm})$ were pressure applied to STN neurons in acute brain slices and current responses were recorded by whole-cell voltage-clamp $\left(V_{\text {HOLD }}-60 \mathrm{mV}\right) . \boldsymbol{B}$, Effects of bath application of TCN-201 $(10 \mu \mathrm{M})$, ifenprodil $(3 \mu \mathrm{M}), \mathrm{DQP}-1105(20 \mu \mathrm{M}), \mathrm{CIQ}(20 \mu \mathrm{M})$, and vehicle $(0.1 \%$ DMSO) on the peak amplitudes of current responses were plotted as the percentage of baseline aCSF responses. Open gray circles represent individual values, the horizontal black lines are the group means. Error bars indicate SEM. The data were analyzed by one-way ANOVA $\left(F_{(4,24)}=34.628, p<0.001\right)$ and post hoc Dunnett's test versus the vehicle group (vehicle: $n=$ 5; TCN-201: $n=6, p=0.999$; ifenprodil: $n=6,{ }^{*} p=0.002$; DQP-1105: $n=6, \neq p=0.004$; and $\mathrm{CIQ}: n=6, \# p<0.001) . n$ is the number of brain slices. Representative current recordings (left) and plots of the peak amplitude for each sweep expressed as a percentage of mean baseline response (right) are shown for $3 \mu \mathrm{m}$ ifenprodil (C), $10 \mu \mathrm{m}$ DQP-1105 (D), and $20 \mu \mathrm{m}$ CIQ $(\boldsymbol{E})$. The black bars depict the period of drug application.

sible that kainate receptors are expressed at a subset of excitatory synapses in the STN. Altogether, these data suggest that the majority of the EPSC responses in the STN are mediated by NMDA and AMPA receptors, with NMDA receptors controlling the slow time course of these currents.

\section{GluN2B- and GluN2D-containing receptors mediate the} NMDA receptor component of EPSCs in the STN

To determine the contributions of the GluN2B and GluN2D subunits to synaptic activity in the STN, EPSCs were evoked in the presence of GluN2B- or GluN2C/D-selective NMDA receptor modulators. The GluN2B-selective antagonist ifenprodil ( $3 \mu \mathrm{M})$ significantly reduced the peak amplitude and total charge transfer
A

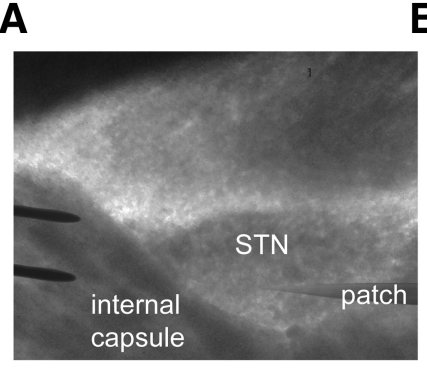

B

C
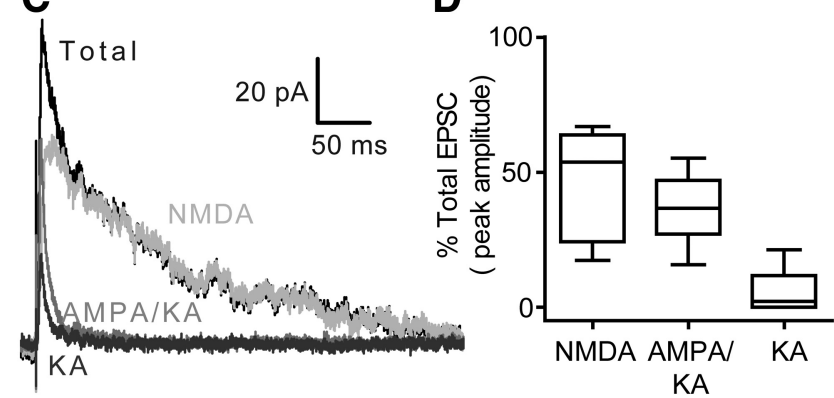

Figure 4. NMDA and AMPA receptors mediate the majority of EPSCs in the STN. $\boldsymbol{A}$, Representative recording arrangement used to evoke EPSCs with a bipolar tungsten-stimulating electrode placed in the internal capsule rostral to the STN. $\boldsymbol{B}$, The current-voltage relationships for the NMDA component of STN EPS(s were acquired in the presence of $20 \mu \mathrm{m}$ DNQX and either $0.2 \mathrm{~mm} \mathrm{Mg}^{2+}(n=4)$ or $1.5 \mathrm{~mm} \mathrm{Mg}^{2+}(n=4)$. The currents were normalized to the peak EPSC amplitudes recorded at $+60 \mathrm{mV}$ for each condition. $C$, In the representative trace, AMPA and kainate receptors were isolated by bath application of $400 \mu \mathrm{m}$ D, L-APV and $50 \mu \mathrm{m}$ 7-CKA (gray).

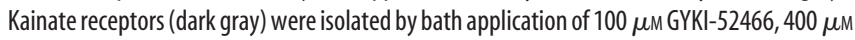
$D, L-A P V$, and $50 \mu \mathrm{m}$ 7-CKA. The NMDA receptor component (light gray) was determined by subtracting the EPSC response recorded in the presence of $400 \mu \mathrm{M} \mathrm{D}, \mathrm{L}-\mathrm{APV}$ and $50 \mu \mathrm{M}$ 7-CKA from the total evoked EPSC recorded in aCSF alone (black). $D$, Comparison of the peak responses of evoked EPSCs in the presence of DNQX (NMDA, $n=14)$, D, L-APV and 7-CKA (AMPA/KA, $n=8)$, or GYKI-52466, D, L-APV, and 7-CKA (KA, $n=8)$ are shown as a percentage of total EPSC amplitude. $n$ is the number of brain slices. The horizontal line is the median value, the box is the 25-75 percentile, and the whiskers are the $10-90$ percentile.

\section{Table 1. Deactivation time courses of subthalamic EPSCs}

\begin{tabular}{llcllr}
\hline Receptor EPSC & $\tau_{\text {FAST }}(\mathrm{ms})$ & $\tau_{\text {SLOW }}(\mathrm{ms})$ & $\tau_{\mathrm{W}}(\mathrm{ms})$ & $\% \tau_{\text {FAST }}$ & $n$ \\
\hline Total & $36 \pm 4.4$ & $240 \pm 43$ & $109 \pm 10$ & $58 \pm 3.3$ & 25 \\
NMDAR & $53 \pm 12$ & $268 \pm 39$ & $154 \pm 16^{*}$ & $49 \pm 5.8$ & 13 \\
AMPAR/KAR & $11 \pm 1.9$ & $73 \pm 12$ & $27 \pm 3.6^{\ddagger}$ & $71 \pm 4.3$ & 11 \\
KAR & $15 \pm 2.0$ & $86 \pm 13$ & $26 \pm 1.8^{\ddagger}$ & $81 \pm 3.9$ & 8 \\
\hline
\end{tabular}

$\tau_{\mathrm{W}}$ values were compared by one-way ANOVA $\left(F_{(3,53)}=22.724, p<0.001\right)$ and post hoc Tukey's tests $\left({ }^{*} p=0.029\right.$ ${ }^{\ddagger} p<0.001$ vs total). $n$ is the number of slices.

of the EPSCs to $67 \pm 6.5 \%$ and $66.5 \pm 6.1 \%$ of baseline EPSCs, respectively $(n=14$; Fig. $5 A, D, E)$. The GluN2C/D-selective inhibitor DQP-1105 (20 $\mu \mathrm{M})$ significantly decreased the peak amplitude and the total charge transfer of the current responses to $59 \pm 8.4 \%$ and $62 \pm 12 \%$ of baseline aCSF responses, respectively $(n=7$; Fig. $5 B, D, E)$. The GluN2C/D-positive allosteric modulator CIQ $(20 \mu \mathrm{M})$ increased the peak amplitude and total charge transfer of evoked currents to $156 \pm 13 \%$ and $137 \pm 10 \%$ of baseline responses, respectively $(n=13$; Fig. $5 C-E)$. The vehicle control $(0.1 \%$ DMSO) did not affect the peak amplitude ( $99 \pm$ $3.2 \%, n=12$; Fig. $5 D)$ or the total charge transfer $(98 \pm 4.9 \%$; Fig. $5 E$ ) of EPSCs. These data suggest that NMDA receptors containing the GluN2B and GluN2D subunits mediate excitatory synaptic currents in the STN.

To demonstrate the specificity of the GluN2C/D-selective modulators used in this study, EPSCs were evoked in STN slices 

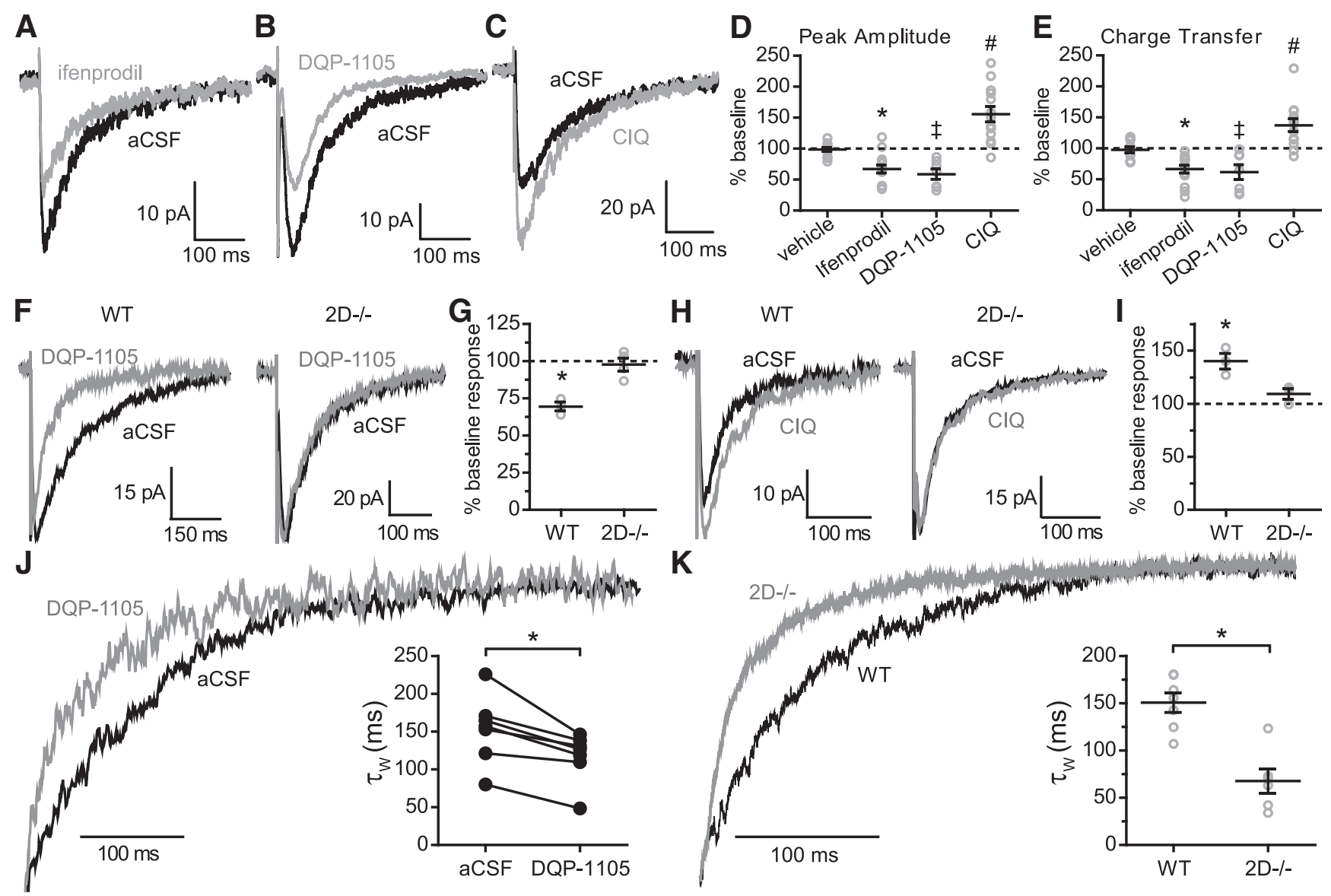

Figure 5. GluN2B- and GluN2D-selective NMDA receptor modulators alter evoked EPSCs in the STN. NMDAR-EPSCs were evoked in STN neurons held at $-40 \mathrm{mV}$ in the presence of $0.2 \mathrm{~mm}$ Mg ${ }^{2+}$ and $20 \mu \mathrm{m}$ DNQX. Representative EPSC traces from rat STN neurons are shown for baseline aCSF responses (black) and after application of each modulator (gray): ifenprodil ( $3 \mu \mathrm{m} ; A)$, DQP-1105 (20 $\mu \mathrm{M} ; \boldsymbol{B})$, and $\mathrm{CIQ}(20 \mu \mathrm{m} ; \boldsymbol{C})$. The peak amplitude $(\boldsymbol{D})$ and charge transfer $(\boldsymbol{E})$ for evoked EPSCs are shown as a percentage of baseline responses for vehicle $(0.1 \%$ DMSO,$n=12)$, ifenprodil $(n=14)$, DQP-1105 $(n=7)$, and CIQ $(n=13)$. The data were analyzed by one-way ANOVA and posthoc Dunnett's test versus the vehicle group. Peak amplitude: $F_{(3,42)}=25.63, p<0.001 ;{ }^{*} p=0.047, \neq p=$ 0.0343 , \#p $=0.0001$. Charge transfer: $F_{(3,42)}=18.428, p<0.001 ;{ }^{*} p=0.037, \neq p=0.047, \# p=0.007$. F, Representative EPSC traces from STN neurons in WT and GluN2D ${ }^{-1-}$ mouse slices are

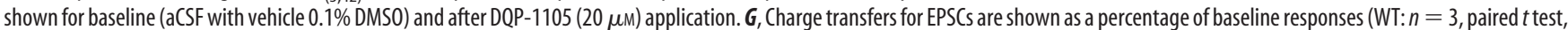
${ }^{*} p=0.043 ; 2 \mathrm{D}^{-I-}: n=4$, paired $t$ test, $\left.p=0.866\right)$. $\boldsymbol{H}$, Representative EPSC traces from WT and GluN2D ${ }^{-1-}$ slices are shown for baseline (aCSF with vehicle $0.1 \%$ DMSO) and after CIQ (20 $\left.\mu \mathrm{M}\right)$ application. $I$, Charge transfers for EPSCs are shown as a percentage of baseline responses (WT: $n=3$, paired $t$ test, ${ }^{*} p=0.017 ; 2 D^{-1-}: n=3$, paired $t$ test, $p=0.206$ ). $J$, EPSC deactivation traces are shown for a representative rat STN neuron at baseline (aCSF) and after DQP-1105 application. The paired weighted tau values are plotted for each cell $\left(n=7,{ }^{*} p=0.004 ;\right.$ see Table 2 for time constants and details of the statistical analysis). $\boldsymbol{K}$, EPSC deactivation traces are shown for representative neurons from WT and GluN2D ${ }^{-1-}$ mice and the weighted tau values are plotted for each cell (WT: $n=7,2 \mathrm{D}^{-1-}: n=6,{ }^{*} p=0.004$; see Table 3 for time constants). For all graphs, the open gray circles represent individual values, the horizontal black lines are the group means, and the error bars are SEM. $n$ is the number of brain slices.

from WT and GluN2D ${ }^{-1-}$ mice in the absence and presence of DQP-1105 and CIQ. In WT neurons, DQP-1105 significantly reduced the total charge transfer of EPSCs to $69.5 \pm 3.0 \%$ of baseline (Fig. $5 F, G$ ) and the peak amplitude of EPSCs was reduced to $74.4 \pm 0.9 \%$ of baseline ( $n=3$, paired $t$ test, $p=0.006$ ). DQP-1105 had no significant effect on EPSC charge transfer (97.9 $\pm 4.4 \%$ of baseline; Fig. $5 F, G)$ or peak amplitude in GluN2D ${ }^{-1-}$ neurons $(106 \pm 2.9 \%$ of baseline, $n=4$, paired $t$ test, $p=0.169$ ). CIQ significantly increased EPSC total charge transfer $(140 \pm 7.4 \%$ of baseline; Fig. $5 H, I)$, as well as peak amplitude in WT neurons ( $118 \pm 0.1 \%$ of baseline, $n=3$, paired $t$ test, $p=0.002)$. However, in GluN2D ${ }^{-1-}$ neurons, CIQ had no significant effect on EPSC total charge transfer $(109 \pm 5.0 \%$ of baseline; Fig. $5 \mathrm{H}, \mathrm{I})$ or peak amplitude $(99.8 \pm 8.7 \%$ of baseline, $n=3$, paired $t$ test, $p=0.428$ ). These data provide evidence that the effects of the GluN2C/D-selective modulators were mediated by GluN2D-containing NMDA receptors in the STN.

GluN2D immunoreactivity was occasionally detected in axon terminals synapsing upon the STN; therefore, we also evaluated whether the GluN2D subunit had a presynaptic effect on EPSCs by testing whether the paired-pulse ratio was altered by potentiation of GluN2D-containing NMDA receptors with CIQ. The paired-pulse ratio was $1.4 \pm 0.10$ in aCSF with a $50 \mathrm{~ms}$ interval between pulses and bath application of $20 \mu \mathrm{M}$ CIQ did not significantly alter the paired-pulse ratio $(1.5 \pm 0.13, n=5$, paired $t$ test, $p=0.239$ ). These data suggest that potentiation of GluN2Dcontaining NMDA receptors does not alter presynaptic glutamate release.

\section{Loss of GluN2D function accelerates the EPSC deactivation time course in the STN}

NMDA receptors containing GluN2D have slower deactivation kinetics compared with the other GluN2 subunits (Traynelis et al., 2010), raising the possibility that GluN2D expression would slow the decay time of EPSCs in the STN. To test this hypothesis, we compared the deactivation time constants for EPSCs evoked at baseline in aCSF to those after application of subunit-selective modulators. DQP-1105 significantly decreased the time constant 
Table 2. EPSC deactivation time course is accelerated by GluN2D inhibition

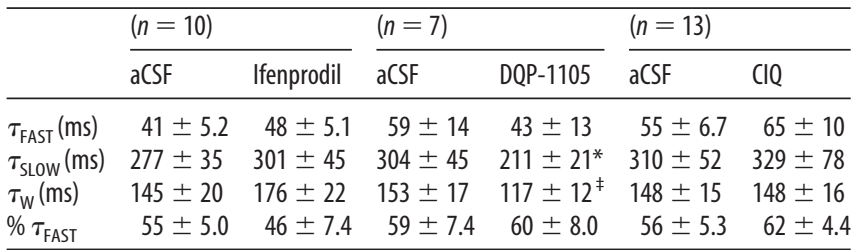

Time constants were analyzed by one-way ANOVAs $\left(\tau_{\mathrm{FAST}}: F_{(5,50)}=2.356, p=0.053 ; \tau_{\mathrm{SLOW}}: F_{(5,50)}=4.01, p=\right.$ $\left.0.014 ; \tau_{\mathrm{W}}: F_{(5,54)}=3.58, p=0.023 ; \% \tau_{\mathrm{FAST}}: F_{(5,50)}=0.876, p=0.504\right)$ and post hoc Bonferroni comparisons were performed between aCSF and drug (ifenprodil $\tau_{\text {SLow }}: p=0.54, \tau_{\mathrm{W}}: p=0.139 ; \mathrm{DQP}-1105^{*} p=0.037,{ }^{\ddagger} p=$ $\left.0.004 ; \mathrm{ClQ} \tau_{\text {SLow }}: p=0.961, \tau_{\mathrm{W}}: p=0.527\right)$. The reported values are mean \pm SEM. $n$ is the number of slices.

Table 3. EPSC deactivation time course is accelerated in the STN of GluN2D ${ }^{-/-}$ mice

\begin{tabular}{llllll}
\hline Genotype & $\tau_{\text {FAST }}(\mathrm{ms})$ & $\tau_{\text {SLOW }}(\mathrm{ms})$ & $\tau_{\mathrm{W}}(\mathrm{ms})$ & $\% \tau_{\text {FAST }}$ & $n$ \\
\hline WT & $150 \pm 10$ & $61.1 \pm 7.6$ & $338 \pm 44$ & $62.5 \pm 5.8$ & 7 \\
GluN2D $^{-1-}$ & $67.8 \pm 12^{*}$ & $32.6 \pm 7.2^{\ddagger}$ & $144 \pm 27^{\#}$ & $65.1 \pm 7.8$ & 6
\end{tabular}

Time constants were compared between WT and GluN2D ${ }^{-1-}$ groups by Student's t test: ${ }^{*} p=0.02,{ }^{\ddagger} p=0.004$, ${ }^{\#} p=0.004, \% \tau_{\text {FAST }}$ was not significant $(p=0.792)$. The reported values are mean \pm SEM N is the number of slices.

for the slow component and the weighted time constant of EPSCs compared with baseline ( $n=7$; Fig. 5J, Table 2$)$. Neither ifenprodil nor CIQ significantly affected the EPSC deactivation time course (Table 2). The role of GluN2D in controlling the EPSC time course was further evaluated by comparing EPSC deactivation times in STN slices from WT and GluN2D ${ }^{-1-}$ mice. The deactivation time constants for the fast and slow components of NMDAR-EPSCs recorded from GluN2D ${ }^{-1-}$ neurons were significantly reduced compared with WT EPSCs (Fig. 5K, Table 3). Together, these data suggest that synaptic GluN2D-containing NMDA receptors contribute to the time course of EPSCs in the STN.

\section{NMDA receptor deactivation rates in the STN are consistent with recombinant GluN2B- and GluN2D-containing receptors}

Given that NMDA receptors containing distinct subunits have different deactivation rates, we evaluated whether the time course obtained for the NMDA receptor component of EPSCs in the STN was consistent with the deactivation time course of recombinant GluN2B- or GluN2D-containing NMDA receptors. For these experiments, we transiently transfected HEK cells with GluN2B or GluN2D, along with GluN1-1a or GluN1-1b. These two different splice variants of GluN1 were used because the variants containing exon 5 (GluN1-1b/2b/3b/4b) have been proposed to be expressed in STN neurons and exon 5-containing NMDA receptors have an accelerated deactivation time course after glutamate removal (Standaert et al., 1993; Laurie and Seeburg, 1994; Winkler et al., 1999; Rumbaugh et al., 2000; Vance et al., 2012).

The recombinant NMDA receptors were activated by rapid application of $1 \mathrm{~mm}$ L-glutamate for 2-4 s (0.05 mM glycine was present in all solutions) and the deactivation time constant was determined upon rapid removal of L-glutamate. To compare the time courses with those obtained from evoked NMDAR-EPSCs in STN slices, we evaluated the temperature sensitivity of recombinant NMDA receptor deactivation by recording at both $23^{\circ} \mathrm{C}$ and $32^{\circ} \mathrm{C}$. As expected, the deactivation time course of recombinant NMDA receptors was accelerated at $32^{\circ} \mathrm{C}$ compared with recordings obtained at $23^{\circ} \mathrm{C}$ (Fig. 6A, Table 4), similar to what has been observed previously for NMDA receptors (Cais et al., 2008). Furthermore, GluN1-1b/GluN2B receptors had a more rapid deactivation time course compared with GluN1-1a/GluN2B receptors (Fig. 6 A, Table 4; see also Vance et al., 2012). Likewise, the deacti-
A

A GluN1-1a/2B
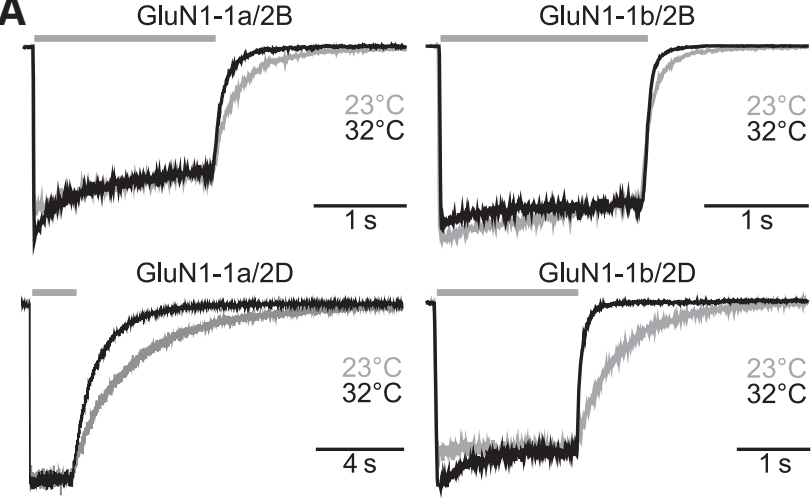

GluN1-1b/2D
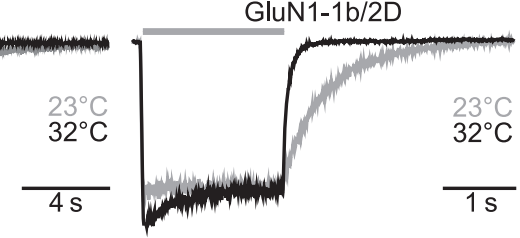

B

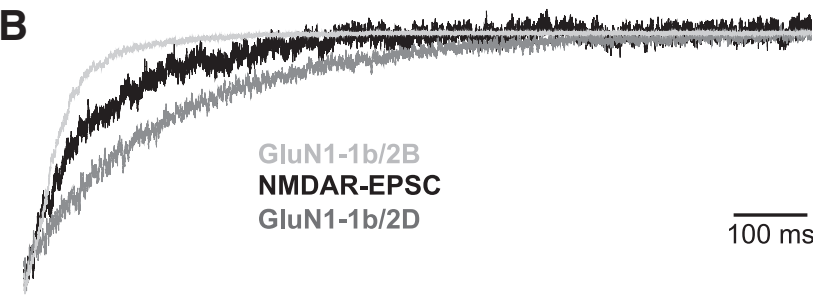

Figure 6. Deactivation time course of NMDAR-EPSCS is consistent with that of recombinant NMDA receptors. A, Recombinant GluN1-1a/GluN2B, GluN1-1b/GluN2B, GluN1-1a/GluN2D, and GluN1-1b/GluN2D receptors were expressed in HEK cells and were activated by 2-4 s application of $1 \mathrm{~mm} \mathrm{L-glutamate}$ and $0.05 \mathrm{~mm}$ glycine (gray bars) at either $23^{\circ} \mathrm{C}$ (gray) or $32^{\circ} \mathrm{C}$ (black). Responses were normalized and superimposed at the two temperatures. $\boldsymbol{B}$, Normalized deactivation time courses of GluN1-1b/GluN2B and GluN1-1b/GluN2D at $32^{\circ} \mathrm{C}$ superimposed on the deactivation time course of the NMDA receptor component of an evoked EPSC from a representative STN neuron.

Table 4. NMDA receptor deactivation times are sensitive to temperature and GluN1 variant

\begin{tabular}{cccccr}
\hline & $\tau_{\text {FAST }}(\mathrm{ms})$ & $\tau_{\text {SLOW }}(\mathrm{ms})$ & $\tau_{\mathrm{W}}(\mathrm{ms})$ & $\% \tau_{\text {FAST }}$ & $n$ \\
\hline $23^{\circ} \mathrm{C}$ & & & & & \\
$1 \mathrm{a} / 2 \mathrm{~B}$ & $180 \pm 18$ & $1100 \pm 370$ & $360 \pm 53$ & $70 \pm 14$ & 5 \\
$1 \mathrm{~b} / 2 \mathrm{~B}$ & $180 \pm 74$ & $630 \pm 120$ & $210 \pm 68$ & $93 \pm 2.0$ & 6 \\
$1 \mathrm{a} / 2 \mathrm{D}$ & $1500 \pm 110$ & $4000 \pm 590$ & $3100 \pm 150$ & $30 \pm 15$ & 3 \\
$1 \mathrm{~b} / 2 \mathrm{D}$ & $270 \pm 52$ & $860 \pm 47$ & $650 \pm 22$ & $36 \pm 3.9$ & 5 \\
$32^{\circ} \mathrm{C}$ & & & & & \\
$1 \mathrm{a} / 2 \mathrm{~B}$ & $100 \pm 6.5$ & $380 \pm 39$ & $150 \pm 7.0$ & $84 \pm 2.7$ & 4 \\
$1 \mathrm{~b} / 2 \mathrm{~B}$ & $49 \pm 4.4$ & $290 \pm 97$ & $75 \pm 4.0$ & $66 \pm 19$ & 5 \\
$1 \mathrm{a} / 2 \mathrm{D}$ & $450 \pm 98$ & $1400 \pm 94$ & $1200 \pm 7.8$ & $25 \pm 8.7$ & 5 \\
$\mathrm{1b} / 2 \mathrm{D}$ & $210 \pm 23$ & $630 \pm 110$ & $340 \pm 25$ & $61 \pm 11$ & 5 \\
\hline
\end{tabular}

Reported values are mean \pm SEM. $n$ is the number of cells. The main effects of splice variant $(V)$ and temperature $(T)$ were analyzed by two-way ANOVA for GluN2B $\left(\tau_{\mathrm{FAST}}: F_{\mathrm{V}(1,14)}=26.56, p<0.001, F_{\mathrm{T}(1,14)}=26.05, p<0.001\right.$; $\tau_{\mathrm{SLOW}}: F_{\mathrm{V}(1,16)}=1.70, p=0.212, F_{\mathrm{T}(1,16)}=6.20, p=0.025 ; \tau_{\mathrm{W}}: F_{\mathrm{V}(1,16)}=5.32, p=0.035, F_{\mathrm{T}(1,16)}=11.64, p=$ $\left.0.004 ; \% \tau_{\mathrm{FAST}}: F_{\mathrm{V}(1,16)}=1.83, p=0.196, F_{\mathrm{T}(1,16)}=0.04, p=0.952\right)$ and GluN2D $\left(\tau_{\mathrm{FAST}}: F_{\mathrm{V}(1,12)}=112.91, p<\right.$ $0.001, F_{\mathrm{T}(1,12)}=64.70, p<0.001 ; \tau_{\mathrm{SLOW}}: F_{\mathrm{V}(1,14)}=89.18, p<0.001, F_{\mathrm{T}(1,14)}=44.90, p<0.001 ; \tau_{\mathrm{W}}: F_{\mathrm{V}(1,14)}=$

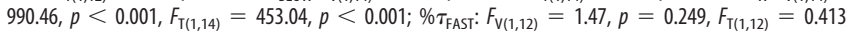
$p=0.533)$.

vation time course of GluN1-1b/GluN2D receptors was significantly faster than that of GluN1-1a/GluN2D receptors (Fig. $6 A$, Table 4). Notably, the deactivation time course observed for the NMDA receptor component of EPSCs in the STN is intermediate between the deactivation time components of recombinant GluN1-1b/GluN2B and GluN1-1b/GluN2D at $32^{\circ} \mathrm{C}$ (Fig. $6 \mathrm{~B}$, Tables 1,4 ). This result is consistent with the hypothesis that NMDA receptors containing GluN2B and/or GluN2D subunits mediate EPSCs in the STN.

\section{GluN2D modulators alter spike firing in vivo}

GluN2D-containing receptors could contribute to the resting excitability in the STN due to their high sensitivity to glutamate, 

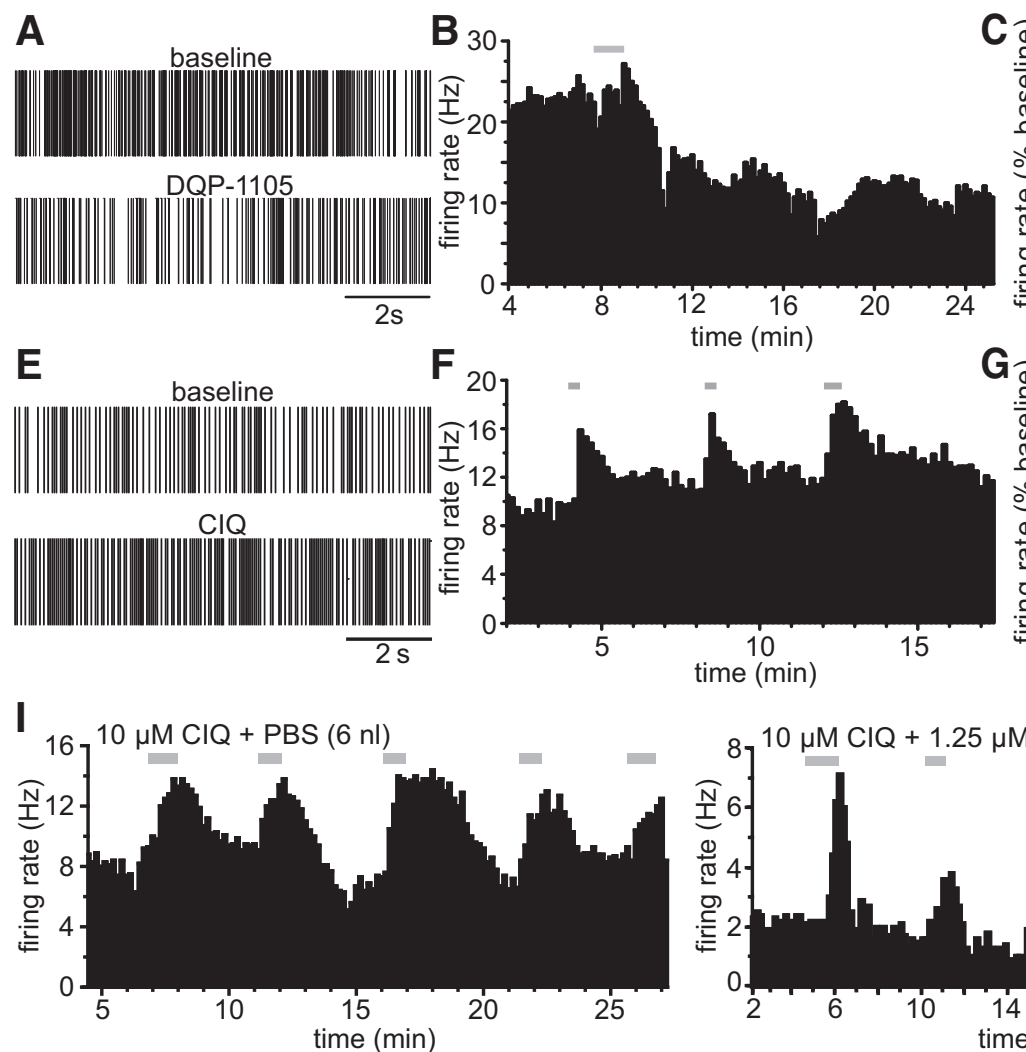
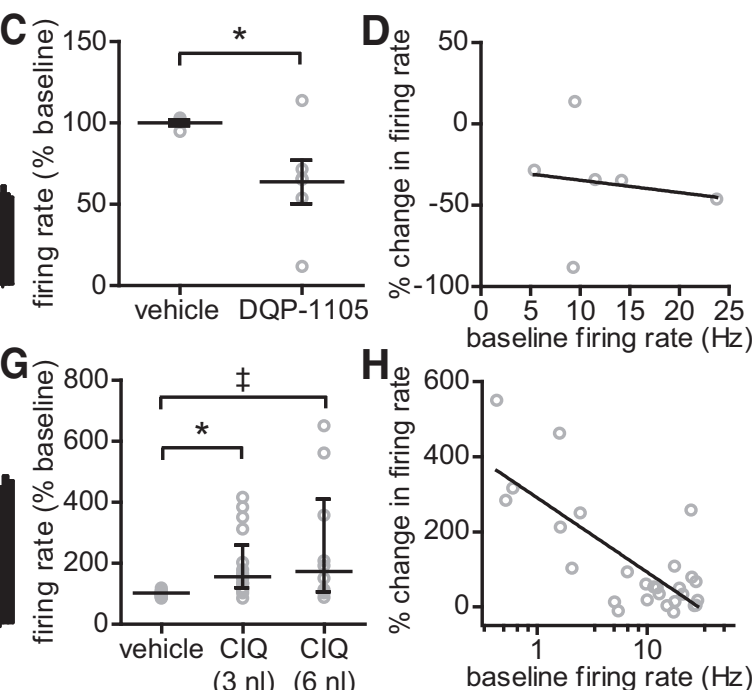

baseline firing rate $(\mathrm{Hz})$
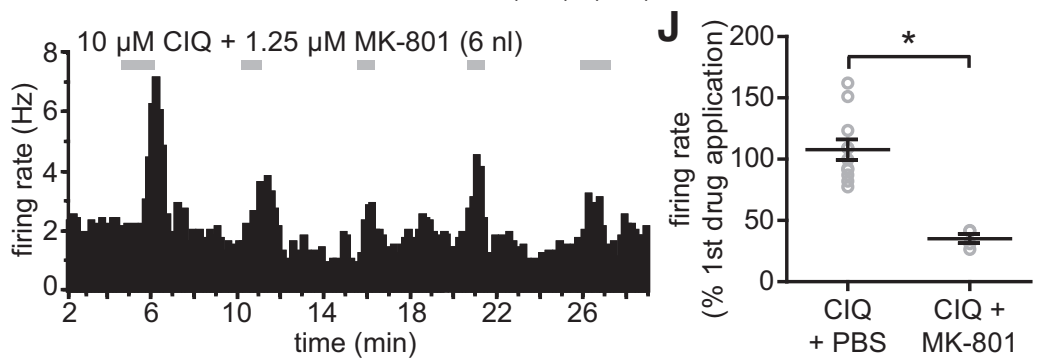

Figure 7. Modulation of GluN2D-containing NMDA receptors alters the firing rate of STN neurons in vivo. Extracellular single-cell recordings were performed in the STN of anesthetized adult male rats. The drug or vehicle control (0.1\% DMSO) was applied locally to the STN after 5 min of stable baseline recording. $\boldsymbol{A}$, Representative spike trains from periods before and after application of DQP-1105 are shown. B, DQP-1105 application (gray bar) caused a long-lasting decrease in firing rate, as demonstrated by a plot of firing rate versus time from a representative STN neuron. $C$, Firing rates for vehicle $(n=4)$ - and DQP-1105 $(n=6)$-treated groups graphed as a percentage of the baseline firing rate (Student's $t$ test, $\left.{ }^{*} p=0.043\right)$. $D$, Baseline firing rate was plotted versus the DQP-1105-induced change in firing rate and analyzed by linear regression (regression line shown in black; $r^{2}=0.022 ; p=0.781$ compared with zero). $\boldsymbol{E}$, Representative spike trains from periods before and after $\mathrm{Cl}$ application are shown. $\boldsymbol{F}$, Plot of firing rate versus time is given for a representative STN neuron to which CIQ (20 $\mu \mathrm{M})$ was applied three times (gray bars). $\boldsymbol{G}$, Firing rates for groups treated with vehicle $(n=18), 3 \mathrm{nl}$ of $\mathrm{ClQ}(n=17)$, and $6 \mathrm{nl}$ of $\mathrm{CIQ}(n=10)$ expressed as a percentage of the baseline firing rate. The data were analyzed by Kruskal-Wallis ANOVA and Dunn's multiple-comparisons test $\left(\chi^{2}(2)=19.803, p<0.001,{ }^{*} p<0.001, \neq p=0.003\right.$, CIQ $3 \mathrm{nl}$ vs CIQ $\left.6 \mathrm{nl}: p=0.861\right]$. $\boldsymbol{H}$, Least squares fitting determined that the relationship between the CIQ-induced change in firing rate and the baseline firing rate was best-fit by a one-phase exponential decay function $\left(r^{2}=0.695\right)$. For presentation, the percentage change in firing rate was plotted against the log transform of the baseline firing rate for each cell and fit with a regression line. $I$, Either CIQ + PBS $(n=4)$ or CIQ + MK-801 $(n=4)$ were applied to the STN 5 times over $\sim 30$ min (gray bars) during extracellular recordings.J, Graph showing the mean firing rate for each animal after the second through fifth drug applications as a percentage of the firing rate after the first drug application. MK-801 requires channel opening before block, so the initial application of CIO + MK-801 increased the firing rate, whereas the effects of subsequent applications were blocked by MK-801 (Student's $t$ test, ${ }^{*} p=0.001$ ). The open gray circles represent individual values, the horizontal black lines are the group means, and the error bars are SEM. $n$ is the number of cells.

prolonged deactivation time course, and weak magnesium sensitivity, as well as their ability to mediate substantial charge transfer and calcium influx into the neuron (Carmignoto and Vicini, 1992; Monyer et al., 1994; Erreger et al., 2005). We therefore tested whether modulating GluN2D-containing receptors altered STN firing rate under resting conditions in vivo. DQP-1105 or CIQ was injected into the STN of anesthetized adult rats and extracellular action potentials were recorded from individual STN neurons. Inhibition of GluN2D-containing NMDA receptors by direct injection of DQP-1105 (3 nl) significantly decreased the firing rate to $63 \pm 14 \%$ of the baseline rate, with a maximal inhibition typically observed between 10 and 20 min after application $(n=6$; Fig. $7 A-C)$. The magnitude of DQP1105 inhibition was not related to the baseline firing rate, as determined by regression analysis (Fig. $7 D$ ). The firing rate of subthalamic neurons was significantly increased by CIQ (3 nl: median $=154 \%$ of baseline, IQR $=118-258 \%, n=17 ; 6$ nl: median $=172 \%$ of baseline, $\mathrm{IQR}=104-409 \%, n=10)$, whereas the vehicle had no effect on baseline firing rate (100\% of baseline, IQR $=93-103, n=18$; Fig. $7 E-G$ ). The magnitude of CIQ potentiation was correlated with the baseline firing rate; CIQ had a large effect on spike firing when the baseline firing rate was low and less of an effect when neurons were already firing at a high baseline rate (Fig. $7 H$ ). The effect of CIQ on spike firing was transient and reversible and significantly attenuated by the NMDA receptor channel blocker MK-801 $(n=4$; Fig. $7 I, J)$. Together, these data suggest that GluN2D-containing NMDA receptors have an important role in regulating spike firing of subthalamic neurons in vivo and that the GluN2D subunit may be a useful pharmacological target for modulating STN activity.

\section{Discussion}

Three main findings of this study demonstrate the potential role of GluN2D-containing NMDA receptors in regulating excitatory synaptic transmission in the rat STN. First, the GluN2D subunit is expressed presynaptically and postsynaptically in subsets of dendrites, axons, and axon terminals in the rat STN. Second, the GluN2D and GluN2B subunits are the predominant GluN2 subunits mediating NMDA receptor function in the developing rat STN. Third, modulation of GluN2D-containing NMDA receptors controls in vivo spike firing in the adult rat STN. These data identify the functional contributions of NMDA receptor sub- 
types to synaptic currents and suggest a key role for the GluN2D subunit in regulating neuronal activity in the STN.

The recent development of pharmacological tools that modulate GluN2D-containing receptors has allowed for functional studies of GluN2D in the nervous system. In the STN, we observed a partial inhibition of EPSCs by the GluN2C/D-selective negative allosteric modulator DQP-1105, which is 40- to 70-fold selective for GluN2D over GluN2A/B (Acker et al., 2011). DQP1105 has also been used to demonstrate GluN2D function at synapses in the spinal cord dorsal horn and the SNc (Hildebrand et al., 2014; Pearlstein et al., 2015). EPSCs in the striatum were partially inhibited by the GluN2C/D-selective inhibitor QNZ46, which is $\sim 50$-fold selective for GluN2D over GluN2A/B (Mosley et al., 2010; Hansen and Traynelis, 2011). The GluN2C/Dselective positive allosteric modulator CIQ (Mullasseril et al., 2010) potentiated subthalamic EPSCs in our study and CIQ was also shown to modulate spike firing and dopamine levels in the striatum (Feng et al., 2014; Zhang et al., 2014). In these studies, it was inferred that the effects of GluN2C/D modulators were mediated by GluN2D, not GluN2C, due to the lack of histological evidence for GluN2C expression in these brain regions (Monyer et al., 1994; Standaert et al., 1994; Wenzel et al., 1996; Wenzel et al., 1997). Our data support a similar conclusion in the STN, given the lack of immunoreactivity of the GluN2C/D antibody in STN tissue from GluN2D ${ }^{-1-}$ mice (Fig. 1). Moreover, we provide evidence that DQP-1105 and CIQ have no significant effect on synaptic transmission in the STN of GluN2D-deficient mice, which further supports the specificity of these modulators and their utility for studying GluN2C/D-containing receptors in native tissues.

The prolonged deactivation time course of NMDAR-EPSCs in the STN is similar to what has been found in other regions proposed to contain synaptic GluN2D (Lozovaya et al., 2004; Brothwell et al., 2008; Harney et al., 2008; Hildebrand et al., 2014; von Engelhardt et al., 2015). This slow deactivation time course could alter the temporal summation of excitatory synaptic inputs into the STN and increase neuronal excitability (Forsythe and Westbrook, 1988; Bourne and Nicoll, 1993; Edmonds et al., 1995). Indeed, longer EPSC deactivation time courses have been linked to stronger synaptic plasticity (Mayer and Miller, 1990; Fox et al., 1991; Carmignoto and Vicini, 1992; Edmonds et al., 1995) and recent studies have suggested a potential role for GluN2D in mediating synaptic plasticity in the hippocampus and striatum (Harney and Anwyl, 2012; Volianskis et al., 2013; Tozzi et al., 2015). GluN2D-containing NMDA receptors may also be expressed at extrasynaptic sites, which could lead to higher tonic NMDA receptor activity in the STN, causing depolarization and increased burst firing (Zhu et al., 2004; Zhu et al., 2005). Several reports have suggested extrasynaptic GluN2D expression in the substantia nigra, hippocampus, and cerebellum (Brickley et al., 2003; Harney et al., 2008; Costa et al., 2009; Wu and Johnson, 2015), but it is unknown whether extrasynaptic NMDA receptors are present in the STN.

Interestingly, many CNS regions that express GluN2D also have a high expression of the GluN2B subunit, including the SNc, $\mathrm{SNr}$, striatum, pallidum, nucleus accumbens, and the dentate gyrus (Monyer et al., 1994; Standaert et al., 1994; Wenzel et al., 1996; Standaert et al., 1999; Brickley et al., 2003). Functional studies have indicated that the GluN2B and GluN2D subunits are concurrently expressed at a subset of synapses in the SNc, striatum, and lamina I neurons of the dorsal horn (Brothwell et al., 2008; Hildebrand et al., 2014). Similarly, the NMDA receptor component of EPSCs in the developing STN was mediated by
GluN2B- and GluN2D-containing receptors. The time course of the NMDA receptor component of STN EPSCs is intermediate between the time course of recombinant GluN1-1b/GluN2B and GluN1-1b/GluN2D (Fig. 5B), further suggesting that the NMDA receptors expressed at STN synapses contain the GluN2B and GluN2D subunits. Studies in SNc neurons have suggested that the GluN2D and GluN2B subunits may be expressed as triheteromeric receptors (Jones and Gibb, 2005; Brothwell et al., 2008; Huang and Gibb, 2014). A similar subunit arrangement may be present at synapses in the STN; however, the proportion of triheteromeric receptors containing GluN1/2B/2D in the STN is unknown. In addition, the relative expression levels of the GluN1 splice variants remain unclear. The stoichiometry of NMDA receptor subunit composition in STN neurons will be important to understand given the likely impact on the functional and pharmacological properties of NMDA receptors.

An additional finding of our study is that the GluN2D subunit is highly expressed in STN neurons throughout postnatal development and in adulthood. Expression of GluN2D in the adult STN was demonstrated by our biochemical, histological, and in vivo spike-firing experiments (Figs. 1, 2, 7). Recent studies have also demonstrated GluN2D protein expression and synaptic function in the adult rodent striatum (Tozzi et al., 2015; Zhang and Chergui, 2015). Historically, studies have shown a marked decrease in GluN2D expression after 1-2 weeks of age across much of the nervous system (Dunah et al., 1996; Wenzel et al., 1996; Laurie et al., 1997; Lau et al., 2003; Shibata et al., 2003; Liu and Wong-Riley, 2010). An age-dependent decrease in GluN2Dmediated synaptic currents was demonstrated in hippocampal interneurons and SNc neurons (Pearlstein et al., 2015; von Engelhardt et al., 2015). Conversely, one study has suggested that GluN2D-containing NMDA receptors are present in adult SNc neurons, but are primarily extrasynaptic ( $\mathrm{Wu}$ and Johnson, 2015). Further investigations of the developmental changes in GluN2D gene expression and subcellular localization will be important for a better understanding of the role of GluN2D in brain function.

Finally, our study has demonstrated that GluN2D modulators can regulate neuronal firing of STN neurons in vivo. These results suggest that either extrasynaptic receptors are tonically active or that excitatory synaptic drive to the STN activates sufficient NMDA receptors such that modulation affects neuronal excitability and thus spike firing. GluN2D-containing receptors have high glutamate potency $(0.5 \mu \mathrm{M}$; Erreger et al., 2007), which is compatible with activation by tonic glutamate, estimated in some tissues to reach $3 \mu \mathrm{M}$ (Edmonds et al., 1995; Timmerman and Westerink, 1997; Rusakov and Kullmann, 1998). In addition, the reduced sensitivity of GluN2D-containing NMDA receptors to $\mathrm{Mg}^{+2}$ inhibition should allow both synaptic and tonic NMDA receptor activation (Monyer et al., 1994; Qian et al., 2005). The role of NMDA receptors in STN firing suggests that targeting the GluN2D subunit could affect the firing rate and perhaps the firing pattern of subthalamic neurons and this could be of therapeutic utility in Parkinson's disease (Hallett and Standaert, 2004). Notably, in an animal model of Parkinson's disease, blocking NMDA receptor function in the STN using a pan-NMDA receptor blocker rectified hypokinetic motor symptoms (Pan et al., 2014). Use of nonselective NMDA receptor blockers is not a viable option for treatments given the side effects associated with both competitive antagonists and channel blockers (Nicholson et al., 1997; Nicholson and Balster, 2003; Yuan et al., 2015). However, if inhibition of NMDA receptors by a GluN2D subunit- 
selective antagonist shows a limited side effect profile, then these antagonists may be of therapeutic interest.

In conclusion, postsynaptic currents at excitatory synapses in the STN contain both NMDA and AMPA receptor components. The NMDA receptor component of excitatory neurotransmission in the developing STN is mediated primarily by GluN2Band GluN2D-containing receptors. Importantly, the GluN2D subunit is expressed in the developing and adult STN and modulating GluN2D-containing NMDA receptor function regulates the spike-firing rate in the adult rat STN. Because increased firing rate and altered firing patterns in the STN contribute to the symptoms of Parkinson's disease (Bergman et al., 1990; DeLong, 1990; Rodríguez et al., 1998; Levy et al., 2000; Obeso et al., 2000), GluN2D-containing NMDA receptors may be a novel therapeutic target for the treatment of this disease.

\section{References}

Acker TM, Yuan H, Hansen KB, Vance KM, Ogden KK, Jensen HS, Burger PB, Mullasseril P, Snyder JP, Liotta DC, Traynelis SF (2011) Mechanism for noncompetitive inhibition by novel GluN2C/D N-methyl-Daspartate receptor subunit-selective modulators. Mol Pharmacol 80: 782-795. CrossRef Medline

Afsharpour S (1985) Topographical projections of the cerebral-cortex to the subthalamic nucleus. J Comp Neurol 236:14-28. CrossRef Medline

Alegre M, Valencia M (2013) Oscillatory activity in the human basal ganglia: more than just beta, more than just Parkinson's disease. Exp Neurol 248: 183-186. CrossRef Medline

Atherton JF, Wokosin DL, Ramanathan S, Bevan MD (2008) Autonomous initiation and propagation of action potentials in neurons of the subthalamic nucleus. J Physiol 586:5679-5700. CrossRef Medline

Awad H, Hubert GW, Smith Y, Levey AI, Conn PJ (2000) Activation of metabotropic glutamate receptor 5 has direct excitatory effects and potentiates NMDA receptor currents in neurons of the subthalamic nucleus. J Neurosci 20:7871-7879. Medline

Baufreton J, Kirkham E, Atherton JF, Menard A, Magill PJ, Bolam JP, Bevan MD (2009) Sparse but selective and potent synaptic transmission from the globus pallidus to the subthalamic nucleus. J Neurophysiol 102: 532-545. CrossRef Medline

Bergman H, Wichmann T, DeLong MR (1990) Reversal of experimental parkinsonism by lesions of the subthalamic nucleus. Science 249: 1436-1438. CrossRef Medline

Bettini E, Sava A, Griffante C, Carignani C, Buson A, Capelli AM, Negri M, Andreetta F, Senar-Sancho SA, Guiral L, Cardullo F (2010) Identification and characterization of novel NMDA receptor antagonists selective for NR2A- over NR2B-containing receptors. J Pharmacol Exp Ther 335: 636-644. CrossRef Medline

Beurrier C, Bioulac B, Hammond C (2000) Slowly inactivating sodium current $(\mathrm{I}(\mathrm{NaP}))$ underlies single-spike activity in rat subthalamic neurons. J Neurophysiol 83:1951-1957. Medline

Bevan MD, Magill PJ, Hallworth NE, Bolam JP, Wilson CJ (2002) Regulation of the timing and pattern of action potential generation in rat subthalamic neurons in vitro by GABA-A IPSPs. J Neurophysiol 87: 1348-1362. Medline

Bischoff S, Barhanin J, Bettler B, Mulle C, Heinemann S (1997) Spatial distribution of kainate receptor subunit mRNA in the mouse basal ganglia and ventral mesencephalon. J Comp Neurol 379:541-562. CrossRef Medline

Bolam JP, Hanley JJ, Booth PA, Bevan MD (2000) Synaptic organisation of the basal ganglia. J Anat 196:527-542. CrossRef Medline

Bolam JP, Magill PJ, Bevan MD (2002) The functional organisation of the basal ganglia: new insights from anatomical and physiological analyses. In: Basal ganglia VII (Nicholson LFB, Faull RLM, eds), pp 371-378. New York: Kluwer Academic/Plenum Publishers.

Bourne HR, Nicoll R (1993) Molecular machines integrate coincident synaptic signals. Cell 72:65-75. CrossRef Medline

Brickley SG, Misra C, Mok MH, Mishina M, Cull-Candy SG (2003) NR2B and NR2D subunits coassemble in cerebellar Golgi cells to form a distinct NMDA receptor subtype restricted to extrasynaptic sites. J Neurosci 23: 4958-4966. Medline

Brothwell SL, Barber JL, Monaghan DT, Jane DE, Gibb AJ, Jones S (2008)
NR2B- and NR2D-containing synaptic NMDA receptors in developing rat substantia nigra pars compacta dopaminergic neurones. J Physiol 586: 739-750. CrossRef Medline

Cais O, Sedlacek M, Horak M, Dittert I, Vyklicky L Jr (2008) Temperature dependence of NR1/NR2B NMDA receptor channels. Neuroscience 151: 428-438. CrossRef Medline

Canteras NS, Shammah-Lagnado SJ, Silva BA, Ricardo JA (1988) Somatosensory inputs to the subthalamic nucleus-a combined retrograde and anterograde horseradish-peroxidase study in the rat. Brain Res 458: 53-64. CrossRef Medline

Carmignoto G, Vicini S (1992) Activity-dependent decrease in nmda receptor responses during development of the visual-cortex. Science 258: 1007-1011. CrossRef Medline

Clarke NP, Bolam JP (1998) Distribution of glutamate receptor subunits at neurochemically characterized synapses in the entopeduncular nucleus and subthalamic nucleus of the rat. J Comp Neurol 397:403-420. Medline

Costa BM, Feng B, Tsintsadze TS, Morley RM, Irvine MW, Tsintsadze V, Lozovaya NA, Jane DE, Monaghan DT (2009) N-methyl-D-aspartate (NMDA) receptor NR2 subunit selectivity of a series of novel piperazine2,3-dicarboxylate derivatives: preferential blockade of extrasynaptic NMDA receptors in the rat hippocampal CA3-CA1 synapse. J Pharmacol Exp Ther 331:618-626. CrossRef Medline

Cragg SJ, Baufreton J, Xue Y, Bolam JP, Bevan MD (2004) Synaptic release of dopamine in the subthalamic nucleus. Eur J Neurosci 20:1788-1802. CrossRef Medline

DeLong MR (1990) Primate models of movement disorders of basal ganglia origin. Trends Neurosci 13:281-285. CrossRef Medline

Dingledine R, Borges K, Bowie D, Traynelis SF (1999) The glutamate receptor ion channels. Pharmacol Rev 51:7-61. Medline

Do MT, Bean BP (2003) Subthreshold sodium currents and pacemaking of subthalamic neurons: modulation by slow inactivation. Neuron 39: 109-120. CrossRef Medline

Dunah AW, Yasuda RP, Wang YH, Luo J, Dávila-Garcia M, Gbadegesin M, Vicini S, Wolfe BB (1996) Regional and ontogenic expression of the NMDA receptor subunit NR2D protein in rat brain using a subunitspecific antibody. J Neurochem 67:2335-2345. Medline

Edman S, McKay S, Macdonald LJ, Samadi M, Livesey MR, Hardingham GE, Wyllie DJ (2012) TCN 201 selectively blocks GluN2A-containing NMDARs in a GluN1 co-agonist dependent but non-competitive manner. Neuropharmacology 63:441-449. CrossRef Medline

Edmonds B, Gibb AJ, Colquhoun D (1995) Mechanisms of activation of glutamate receptors and the time-course of excitatory synaptic currents. Annu Rev Physiol 57:495-519. CrossRef Medline

Erreger K, Dravid SM, Banke TG, Wyllie DJ, Traynelis SF (2005) Subunitspecific gating controls rat NR1/NR2A and NR1/NR2B NMDA channel kinetics and synaptic signalling profiles. J Physiol 563:345-358. CrossRef Medline

Erreger K, Geballe MT, Kristensen A, Chen PE, Hansen KB, Lee CJ, Yuan H, Le P, Lyuboslavsky PN, Micale N, Jørgensen L, Clausen RP, Wyllie DJ, Snyder JP, Traynelis SF (2007) Subunit-specific agonist activity at NR2A-, NR2B-, NR2C-, and NR2D-containing N-methyl-D-aspartate glutamate receptors. Mol Pharmacol 72:907-920. CrossRef Medline

Féger J (1997) Updating the functional model of the basal ganglia. Trends Neurosci 20:152-153. CrossRef Medline

Féger J, Bevan M, Crossman AR (1994) The projections from the parafascicular thalamic nucleus to the subthalamic nucleus and the striatum arise from separate neuronal populations-a comparison with the corticostriatal and corticosubthalamic efferents in a retrograde fluorescent doublelabeling study. Neuroscience 60:125-132. CrossRef Medline

Feng ZJ, Zhang X, Chergui K (2014) Allosteric modulation of NMDA receptors alters neurotransmission in the striatum of a mouse model of Parkinson's disease. Exp Neurol 255:154-160. CrossRef Medline

Forsythe ID, Westbrook GL (1988) Slow excitatory postsynaptic currents mediated by N-methyl-D-aspartate receptors on cultured mouse central neurones. J Physiol 396:515-533. CrossRef Medline

Fox K, Daw N, Sato H, Czepita D (1991) Dark-rearing delays the loss of nmda-receptor function in kitten visual-cortex. Nature 350:342-344. CrossRef Medline

Galvan A, Kuwajima M, Smith Y (2006) Glutamate and GABA receptors and transporters in the basal ganglia: What does their subsynaptic localization reveal about their function? Neuroscience 143:351-375. CrossRef Medline 
Götz T, Kraushaar U, Geiger J, Lubke J, Berger T, Jonas P (1997) Functional properties of AMPA and NMDA receptors expressed in identified types of basal ganglia neurons. J Neurosci 17:204-215. Medline

Guzman JN, Sánchez-Padilla J, Chan CS, Surmeier DJ (2009) Robust pacemaking in substantia nigra dopaminergic neurons. J Neurosci 29:1101111019. CrossRef Medline

Hallett PJ, Standaert DG (2004) Rationale for and use of NMDA receptor antagonists in Parkinson's disease. Pharmacol Ther 102:155-174. CrossRef Medline

Hamani C, Saint-Cyr JA, Fraser J, Kaplitt M, Lozano AM (2004) The subthalamic nucleus in the context of movement disorders. Brain 127:4-20. CrossRef Medline

Hansen KB, Traynelis SF (2011) Structural and mechanistic determinants of a novel site for noncompetitive inhibition of GluN2D-containing NMDA receptors. J Neurosci 31:3650-3661. CrossRef Medline

Hansen KB, Ogden KK, Traynelis SF (2012) Subunit-selective allosteric inhibition of glycine binding to NMDA receptors. J Neurosci 32:61976208. CrossRef Medline

Harney SC, Anwyl R (2012) Plasticity of NMDA receptor-mediated excitatory postsynaptic currents at perforant path inputs to dendrite-targeting interneurons. J Physiol 590:3771-3786. CrossRef Medline

Harney SC, Jane DE, Anwyl R (2008) Extrasynaptic NR2D-Containing NMDARs Are Recruited to the Synapse during LTP of NMDAR-EPSCs. J Neurosci 28:11685-11694. CrossRef Medline

Hassani OK, François C, Yelnik J, Féger J (1997) Evidence for a dopaminergic innervation of the subthalamic nucleus in the rat. Brain Res 749: 88-94. CrossRef Medline

Hildebrand ME, Pitcher GM, Harding EK, Li H, Beggs S, Salter MW (2014) GluN2B and GluN2D NMDARs dominate synaptic responses in the adult spinal cord. Sci Rep 4:4094. Medline

Huang Z, Gibb AJ (2014) Mg2 + block properties of triheteromeric GluN1GluN2B-GluN2D NMDA receptors on neonatal rat substantia nigra pars compacta dopaminergic neurones. J Physiol 592:2059-2078. CrossRef Medline

Ikeda K, Araki K, Takayama C, Inoue Y, Yagi T, Aizawa S, Mishina M (1995) Reduced spontaneous activity of mice defective in the epsilon 4 subunit of the NMDA receptor channel. Brain Res Mol Brain Res 33:61-71. CrossRef Medline

Jakowec MW, Jackson-Lewis V, Chen X, Langston JW, Przedborski S (1998) The postnatal development of AMPA receptor subunits in the basal ganglia of the rat. Dev Neurosci 20:19-33. CrossRef Medline

Jones S, Gibb AJ (2005) Functional NR2B- and NR2D-containing NMDA receptor channels in rat substantia nigra dopaminergic neurones. J Physiol 569:209-221. CrossRef Medline

Karachi C, Yelnik J, Tandé D, Tremblay L, Hirsch EC, François C (2005) The pallidosubthalamic projection: An anatomical substrate for nonmotor functions of the subthalamic nucleus in primates. Mov Disord 20:172180. CrossRef Medline

Karakas E, Furukawa H (2014) Crystal structure of a heterotetrameric NMDA receptor ion channel. Science 344:992-997. CrossRef Medline

Kühn AA, Doyle L, Pogosyan A, Yarrow K, Kupsch A, Schneider GH, Hariz MI, Trottenberg T, Brown P (2006) Modulation of beta oscillations in the subthalamic area during motor imagery in Parkinson's disease. Brain 129:695-706. CrossRef Medline

Kuwajima M, Hall RA, Aiba A, Smith Y (2004) Subcellular and subsynaptic localization of group I metabotropic glutamate receptors in the monkey subthalamic nucleus. J Comp Neurol 474:589-602. CrossRef Medline

Kuwajima M, Dehoff MH, Furuichi T, Worley PF, Hall RA, Smith Y (2007) Localization and expression of group I metabotropic glutamate receptors in the mouse striatum, globus pallidus, and subthalamic nucleus: Regulatory effects of MPTP treatment and constitutive Homer deletion. J Neurosci 27:6249-6260. CrossRef Medline

Lau WK, Lui PW, Wong CK, Chan YS, Yung KK (2003) Differential expression of $\mathrm{N}$-methyl-D-aspartate receptor subunit messenger ribonucleic acids and immunoreactivity in the rat neostriatum during postnatal development. Neurochem Int 43:47-65. CrossRef Medline

Laurie DJ, Seeburg PH (1994) Regional and developmental heterogeneity in splicing of the rat brain NMDAR1 mRNA. J Neurosci 14:3180-3194. Medline

Laurie DJ, Bartke I, Schoepfer R, Naujoks K, Seeburg PH (1997) Regional, developmental and interspecies expression of the four NMDAR2 sub- units, examined using monoclonal antibodies. Mol Brain Res 51:23-32. CrossRef Medline

Lee CH, Lü W, Michel JC, Goehring A, Du J, Song X, Gouaux E (2014) NMDA receptor structures reveal subunit arrangement and pore architecture. Nature 511:191-197. CrossRef Medline

Lee CJ, Mannaioni G, Yuan H, Woo DH, Gingrich MB, Traynelis SF (2007) Astrocytic control of synaptic NMDA receptors. J Physiol 581:1057-1081. CrossRef Medline

Levy R, Hutchison WD, Lozano AM, Dostrovsky JO (2000) High-frequency synchronization of neuronal activity in the subthalamic nucleus of parkinsonian patients with limb tremor. J Neurosci 20:7766-7775. Medline

Litvak V, Jha A, Eusebio A, Oostenveld R, Foltynie T, Limousin P, Zrinzo L, Hariz MI, Friston K, Brown P (2011) Resting oscillatory corticosubthalamic connectivity in patients with Parkinson's disease. Brain 134: 359-374. CrossRef Medline

Liu Q, Wong-Riley MT (2010) Postnatal development of N-methyl-Daspartate receptor subunits $2 \mathrm{~A}, 2 \mathrm{~B}, 2 \mathrm{C}, 2 \mathrm{D}$, and $3 \mathrm{~B}$ immunoreactivity in brain stem respiratory nuclei of the rat. Neuroscience 171:637-654. CrossRef Medline

Lobo MK, Itri JN, Cepeda C, Chavira CA, Levine MS (2003) Ionotropic glutamate receptor expression and dopaminergic modulation in the developing subthalamic nucleus of the rat: an immunohistochemical and electrophysiological analysis. Dev Neurosci 25:384-393. CrossRef Medline

Lozovaya NA, Grebenyuk SE, Tsintsadze TSh, Feng B, Monaghan DT, Krishtal OA (2004) Extrasynaptic NR2B and NR2D subunits of NMDA receptors shape 'superslow' afterburst EPSC in rat hippocampus. J Physiol 558:451-463. CrossRef Medline

Magill PJ, Bolam JP, Bevan MD (2001) Dopamine regulates the impact of the cerebral cortex on the subthalamic nucleus-globus pallidus network. Neuroscience 106:313-330. CrossRef Medline

Magill PJ, Sharott A, Bevan MD, Brown P, Bolam JP (2004) Synchronous unit activity and local field potentials evoked in the subthalamic nucleus by cortical stimulation. J Neurophysiol 92:700-714. CrossRef Medline

Mallet N, Pogosyan A, Márton LF, Bolam JP, Brown P, Magill PJ (2008) Parkinsonian beta oscillations in the external globus pallidus and their relationship with subthalamic nucleus activity. J Neurosci 28:1424514258. CrossRef Medline

Mayer ML, Miller RJ (1990) Excitatory amino-acid receptors, 2nd messengers and regulation of intracellular $\mathrm{Ca}-2+$ in mammalian neurons. Trends Pharmacol Sci 11:254-260. CrossRef Medline

Monyer H, Burnashev N, Laurie DJ, Sakmann B, Seeburg PH (1994) Developmental and regional expression in the rat brain and functional properties of four NMDA receptors. Neuron 12:529-540. CrossRef Medline

Moran RJ, Mallet N, Litvak V, Dolan RJ, Magill PJ, Friston KJ, Brown P (2011) Alterations in brain connectivity underlying beta oscillations in Parkinsonism. PLoS Comput Biol 7:e1002124. CrossRef Medline

Mosley CA, Acker TM, Hansen KB, Mullasseril P, Andersen KT, Le P, Vellano KM, Bräuner-Osborne H, Liotta DC, Traynelis SF (2010) Quinazolin4-one derivatives: A novel class of noncompetitive NR2C/D subunitselective N-methyl-D-aspartate receptor antagonists. J Med Chem 53: 5476-5490. CrossRef Medline

Mott DD, Benveniste M, Dingledine RJ (2008) pH-Dependent inhibition of kainate receptors by zinc. J Neurosci 28:1659-1671. CrossRef Medline

Mullasseril P, Hansen KB, Vance KM, Ogden KK, Yuan H, Kurtkaya NL, Santangelo R, Orr AG, Le P, Vellano KM, Liotta DC, Traynelis SF (2010) A subunit-selective potentiator of NR2C- and NR2D-containing NMDA receptors. Nat Commun 1:90. Medline

Nambu A, Takada M, Inase M, Tokuno H (1996) Dual somatotopical representations in the primate subthalamic nucleus: Evidence for ordered but reversed body-map transformations from the primary motor cortex and the supplementary motor area. J Neurosci 16:2671-2683. Medline

Nicholson KL, Balster RL (2003) Evaluation of the phencyclidine-like discriminative stimulus effects of novel NMDA channel blockers in rats. Psychopharmacology (Berl) 170:215-224. CrossRef Medline

Nicholson KL, Jones HE, Balster RL (1997) Evaluation of the reinforcing and discriminative stimulus effects of the N-methyl-D-aspartate competitive antagonist NPC 17742 in rhesus monkeys. Behav Pharmacol 8:396407. Medline

Obeso JA, Rodríguez-Oroz MC, Rodríguez M, Lanciego JL, Artieda J, Gonzalo N, Olanow CW (2000) Pathophysiology of the basal ganglia in Parkinson's disease. Trends Neurosci 23:S8-S19. CrossRef Medline 
Pan MK, Tai CH, Liu WC, Pei JC, Lai WS, Kuo CC (2014) Deranged NMDAergic cortico-subthalamic transmission underlies parkinsonian motor deficits. J Clin Invest 124:4629-4641. CrossRef Medline

Paxinos G, Watson C (1998) The rat brain in stereotaxic coordinates. Amsterdam: Academic.

Pearlstein E, Gouty-Colomer LA, Michel FJ, Cloarec R, Hammond C (2015) Glutamatergic synaptic currents of nigral dopaminergic neurons follow a postnatal developmental sequence. Front Cell Neurosci 9:210. Medline

Peters A, Palay SL, Webster H (1991) The fine structure of the nervous system: neurons and their supporting cells, Ed 3. New York: OUP.

Prensa L, Cossette M, Parent A (2000) Dopaminergic innervation of human basal ganglia. J Chem Neuroanat 20:207-213. CrossRef Medline

Qian A, Buller AL, Johnson JW (2005) NR2 subunit-depenclence of NMDA receptor channel block by external Mg2+. J Physiol 562:319-331. CrossRef Medline

Rodríguez MC, Obeso JA, Olanow CW (1998) Subthalamic nucleusmediated excitotoxicity in Parkinson's disease: a target for neuroprotection. Ann Neurol 44:S175-188. CrossRef Medline

Rumbaugh G, Prybylowski K, Wang JF, Vicini S (2000) Exon 5 and spermine regulate deactivation of NMDA receptor subtypes. J Neurophysiol 83:1300-1306. Medline

Rusakov DA, Kullmann DM (1998) Extrasynaptic glutamate diffusion in the hippocampus: ultrastructural constraints, uptake, and receptor activation. J Neurosci 18:3158-3170. Medline

Sato K, Kiyama H, Tohyama M (1993) The differential expression patterns of messenger RNAs encoding non-N-methyl-d-aspartate glutamate receptor subunits (GluR1-4) in the rat brain. Neuroscience 52:515-539. CrossRef Medline

Sharott A, Magill PJ, Bolam JP, Brown P (2005) Directional analysis of coherent oscillatory field potentials in the cerebral cortex and basal ganglia of the rat. J Physiol 562:951-963. CrossRef Medline

Shibata T, Watanabe M, Ichikawa R, Ameda K, Koyanagi T (2003) Transient neonatal expression of NR2B/2D subunit mRNAs of the N-methyl$\mathrm{D}$-aspartate receptor in the parasympathetic preganglionic neurons in the rat spinal cord. Brain Res Dev Brain Res 140:263-268. CrossRef Medline

Shink E, Bevan MD, Bolam JP, Smith Y (1996) The subthalamic nucleus and the external pallidum: two tightly interconnected structures that control the output of the basal ganglia in the monkey. Neuroscience 73:335-357. CrossRef Medline

Smith ID, Grace AA (1992) Role of the subthalamic nucleus in the regulation of nigral dopamine neuron activity. Synapse 12:287-303. CrossRef Medline

Standaert DG, Testa CM, Penney JB Jr, Young AB (1993) Alternatively spliced isoforms of the NMDAR1 glutamate receptor subunit: Differential expression in the basal ganglia of the rat. Neurosci Lett 152:161-164. CrossRef Medline

Standaert DG, Testa CM, Young AB, Penney JB Jr (1994) Organization of $\mathrm{N}$-methyl-D-aspartate glutamate receptor gene expression in the basal ganglia of the rat. J Comp Neurol 343:1-16. CrossRef Medline

Standaert DG, Friberg IK, Landwehrmeyer GB, Young AB, Penney JB Jr (1999) Expression of NMDA glutamate receptor subunit mRNAs in neurochemically identified projection and interneurons in the striatum of the rat. Mol Brain Res 64:11-23. CrossRef Medline

Surmeier DJ, Mercer JN, Chan CS (2005) Autonomous pacemakers in the basal ganglia: who needs excitatory synapses anyway? Curr Opin Neurobiol 15:312-318. CrossRef Medline

Timmerman W, Westerink BH (1997) Brain microdialysis of GABA and glutamate: what does it signify? Synapse 27:242-261. CrossRef Medline

Tozzi A, et al. (2015) Alpha-synuclein produces early behavioral alterations via striatal cholinergic synaptic dysfunction by interacting with GluN2D N-methyl-D-aspartate receptor subunit. Biol Psychiatry pii: S00063223(15)00678-2. CrossRef Medline

Traynelis SF, Wollmuth LP, McBain CJ, Menniti FS, Vance KM, Ogden KK,
Hansen KB, Yuan H, Myers SJ, Dingledine R (2010) Glutamate receptor ion channels: structure, regulation, and function. Pharmacol Rev 62:405496. CrossRef Medline

Vance KM, Hansen KB, Traynelis SF (2012) GluN1 splice variant control of GluN1/GluN2D NMDA receptors. J Physiol 590:3857-3875. CrossRef Medline

Volianskis A, Bannister N, Collett VJ, Irvine MW, Monaghan DT, Fitzjohn SM, Jensen MS, Jane DE, Collingridge GL (2013) Different NMDA receptor subtypes mediate induction of long-term potentiation and two forms of short-term potentiation at CA1 synapses in rat hippocampus in vitro. J Physiol 591:955-972. CrossRef Medline

von Engelhardt J, Bocklisch C, Tönges L, Herb A, Mishina M, Monyer H (2015) GluN2D-containing NMDA receptors-mediate synaptic currents in hippocampal interneurons and pyramidal cells in juvenile mice. Front Cell Neurosci 9:95. Medline

Wenzel A, Villa M, Mohler H, Benke D (1996) Developmental and regional expression of NMDA receptor subtypes containing the NR2D subunit in rat brain. J Neurochem 66:1240-1248. Medline

Wenzel A, Fritschy JM, Mohler H, Benke D (1997) NMDA receptor heterogeneity during postnatal development of the rat brain: differential expression of the NR2A, NR2B, and NR2C subunit proteins. J Neurochem 68:469-478. Medline

Williams K (1993) Ifenprodil discriminates subtypes of the N-methyl-Daspartate receptor: selectivity and mechanisms at recombinant heteromeric receptors. Mol Pharmacol 44:851-859. Medline

Wilson CJ, Bevan MD (2011) Intrinsic dynamics and synaptic inputs control the activity patterns of subthalamic nucleus neurons in health and in Parkinson's disease. Neuroscience 198:54-68. CrossRef Medline

Winkler A, Mahal B, Zieglgänsberger W, Spanagel R (1999) Accurate quantification of the mRNA of NMDAR1 splice variants measured by competitive RT-PCR. Brain Res Brain Res Protoc 4:69-81. CrossRef Medline

Wu YN, Johnson SW (2015) Memantine selectively blocks extrasynaptic NMDA receptors in rat substantia nigra dopamine neurons. Brain Res 1603:1-7. CrossRef Medline

Wüllner U, Standaert DG, Testa CM, Penney JB, Young AB (1997) Differential expression of kainate receptors in the basal ganglia of the developing and adult rat brain. Brain Res 768:215-223. CrossRef Medline

Yamawaki N, Magill PJ, Woodhall GL, Hall SD, Stanford IM (2012) Frequency selectivity and dopamine-dependence of plasticity at glutamatergic synapses in the subthalamic nucleus. Neuroscience 203:1-11. CrossRef Medline

Yuan H, Myers SJ, Wells G, Nicholson KL, Swanger SA, Lyuboslavsky P, Tahirovic YA, Menaldino DS, Ganesh T, Wilson LJ, Liotta DC, Snyder JP, Traynelis SF (2015) Context-dependent GluN2B-selective inhibitors of NMDA receptor function are neuroprotective with minimal side effects. Neuron 85:1305-1318. CrossRef Medline

Zhang X, Chergui K (2015) Dopamine depletion of the striatum causes a cell-type specific reorganization of GluN2B- and GluN2D-containing NMDA receptors. Neuropharmacology 92:108-115. CrossRef Medline

Zhang X, Feng ZJ, Chergui K (2014) Allosteric modulation of GluN2C/ GluN2D-containing NMDA receptors bidirectionally modulates dopamine release: implication for Parkinson's disease. Br J Pharmacol 171: 3938-3945. CrossRef Medline

Zheng F, Erreger K, Low CM, Banke T, Lee CJ, Conn PJ, Traynelis SF (2001) Allosteric interaction between the amino terminal domain and the ligand binding domain of NR2A. Nat Neurosci 4:894-901. CrossRef Medline

Zhu ZT, Munhall A, Shen KZ, Johnson SW (2004) Calcium-dependent subthreshold oscillations determine bursting activity induced by N-methylD-aspartate in rat subthalamic neurons in vitro. Eur J Neurosci 19: 1296-1304. CrossRef Medline

Zhu ZT, Munhall A, Shen KZ, Johnson SW (2005) NMDA enhances a depolarization-activated inward current in subthalamic neurons. Neuropharmacology 49:317-327. CrossRef Medline 